Article

\title{
Synthesis of Novel Biologically Active Proflavine Ureas Designed on the Basis of Predicted Entropy Changes
}

\author{
Ladislav Janovec $^{1, *}$, Eva Kovacova ${ }^{1}$, Martina Semelakova ${ }^{2}$, Monika Kvakova ${ }^{3} \mathbb{D}$, Daniel Kupka ${ }^{4}$, David Jager ${ }^{4} \mathbb{D}$ \\ and Maria Kozurkova ${ }^{5,6}$ (D)
}

1 Department of Organic Chemistry, Faculty of Science, P. J. Safarik University in Kosice, Moyzesova 11, 04001 Kosice, Slovakia; evakovacova2702127@gmail.com

2 Department of Medical Biology, Faculty of Medicine, P. J. Safarik University in Kosice, Trieda SNP1, 04011 Kosice, Slovakia; martina.semelakova@upjs.sk

3 Department of Experimental Medicine, Faculty of Medicine, P. J. Safarik University in Kosice, Trieda SNP1, 04011 Kosice, Slovakia; monika.kvakova@upjs.sk

4 Institute of Geotechnics, Slovak Academy of Sciences, Watsonova 45, 04001 Kosice, Slovakia; dankup@saske.sk (D.K.); jager@saske.sk (D.J.)

5 Department of Biochemistry, Faculty of Science, P. J. Safarik University in Kosice, Moyzesova 11, 04001 Kosice, Slovakia; maria.kozurkova@upjs.sk

6 Biomedical Research Center, University Hospital Hradec Kralove, Sokolovska 581, 50005 Hradec Kralove, Czech Republic

* Correspondence: ladislav.janovec@upjs.sk

Citation: Janovec, L.; Kovacova, E.; Semelakova, M.; Kvakova, M.; Kupka, D.; Jager, D.; Kozurkova, M. Synthesis of Novel Biologically Active Proflavine Ureas Designed on the Basis of Predicted Entropy Changes. Molecules 2021, 26, 4860. https:// doi.org/10.3390/molecules26164860

Academic Editor: Tiziano Tuccinardi

Received: 27 July 2021

Accepted: 7 August 2021

Published: 11 August 2021

Publisher's Note: MDPI stays neutral with regard to jurisdictional claims in published maps and institutional affiliations.

Copyright: (C) 2021 by the authors Licensee MDPI, Basel, Switzerland. This article is an open access article distributed under the terms and conditions of the Creative Commons Attribution (CC BY) license (https:/ / creativecommons.org/licenses/by/ $4.0 /)$.
Abstract: A novel series of proflavine ureas, derivatives 11a-11i, were synthesized on the basis of molecular modeling design studies. The structure of the novel ureas was obtained from the pharmacological model, the parameters of which were determined from studies of the structureactivity relationship of previously prepared proflavine ureas bearing $n$-alkyl chains. The lipophilicity $(\log P)$ and the changes in the standard entropy $\left(\Delta S^{\circ}\right)$ of the urea models, the input parameters of the pharmacological model, were determined using quantum mechanics and cheminformatics. The anticancer activity of the synthesized derivatives was evaluated against NCI-60 human cancer cell lines. The urea derivatives azepyl 11b, phenyl 11c and phenylethyl 11f displayed the highest levels of anticancer activity, although the results were only a slight improvement over the hexyl urea, derivative $\mathbf{1 1} \mathbf{j}$, which was reported in a previous publication. Several of the novel urea derivatives displayed $\mathrm{GI}_{50}$ values against the HCT-116 cancer cell line, which suggest the cytostatic effect of the compounds azepyl 11b- $0.44 \mu \mathrm{M}$, phenyl 11c-0.23 $\mu \mathrm{M}$, phenylethyl 11f- $0.35 \mu \mathrm{M}$ and hexyl 11j$0.36 \mu \mathrm{M}$. In contrast, the novel urea derivatives $\mathbf{1 1} \mathbf{b}, \mathbf{1 1} \mathbf{c}$ and $\mathbf{1 1} \mathbf{f}$ exhibited levels of cytotoxicity three orders of magnitude lower than that of hexyl urea $\mathbf{1 1} \mathbf{j}$ or amsacrine.

Keywords: proflavine ureas; molecular design; cytostatic activity; cytotoxicity

\section{Introduction}

Previous studies have shown that compounds based on an acridine chromophore possess a wide range of interesting biological activities [1]. The main type of biological effect exhibited by acridine derivatives is that of antiproliferative activity [2]. The main interaction mode of acridines with biological macromolecules is an intercalation reaction with nucleic acids where an electron-deficient acridine chromophore inserts between adjacent base pairs [3,4]. This process affects cell division on the molecular and enzymatic level, leading to the suppression of further cell proliferation. The enzymatic inhibitory effect of acridine-based compounds takes the form of specific interactions with topoisomerases I/II, whereby the ability to stabilize G-rich sequences of telomeric DNA in the form of a G-quadruplex indirectly inhibits the activity of the enzyme telomerase [5].

Genomic DNA is densely packed and undergoes superhelical strain during the process of cell division. Two principal enzymes are involved in this process: topoisomerases I 
and II. Topo I breaks one strand of duplex DNA transiently and allows the rotation about the unbroken strand, while Topo II enzymes break both strands and passes one region of DNA through the resulting gap. Topoisomerases I/II cleave the phosphodiester backbone through a nucleophilic attack on a tyrosine hydroxyl group, which results in the formation of a covalent bond between the enzyme and the broken strand [6]. Compounds which are capable of interfering with the covalent enzyme-DNA complex are termed topoisomerases poisons. Two major acridine-based agents act as topoisomerase inhibitors within the cell proliferation process: amsacrine-like compounds $\mathbf{1}$ and $\mathbf{2}$ and compounds derived from the structure of DACA 3 (Figure 1) [7].

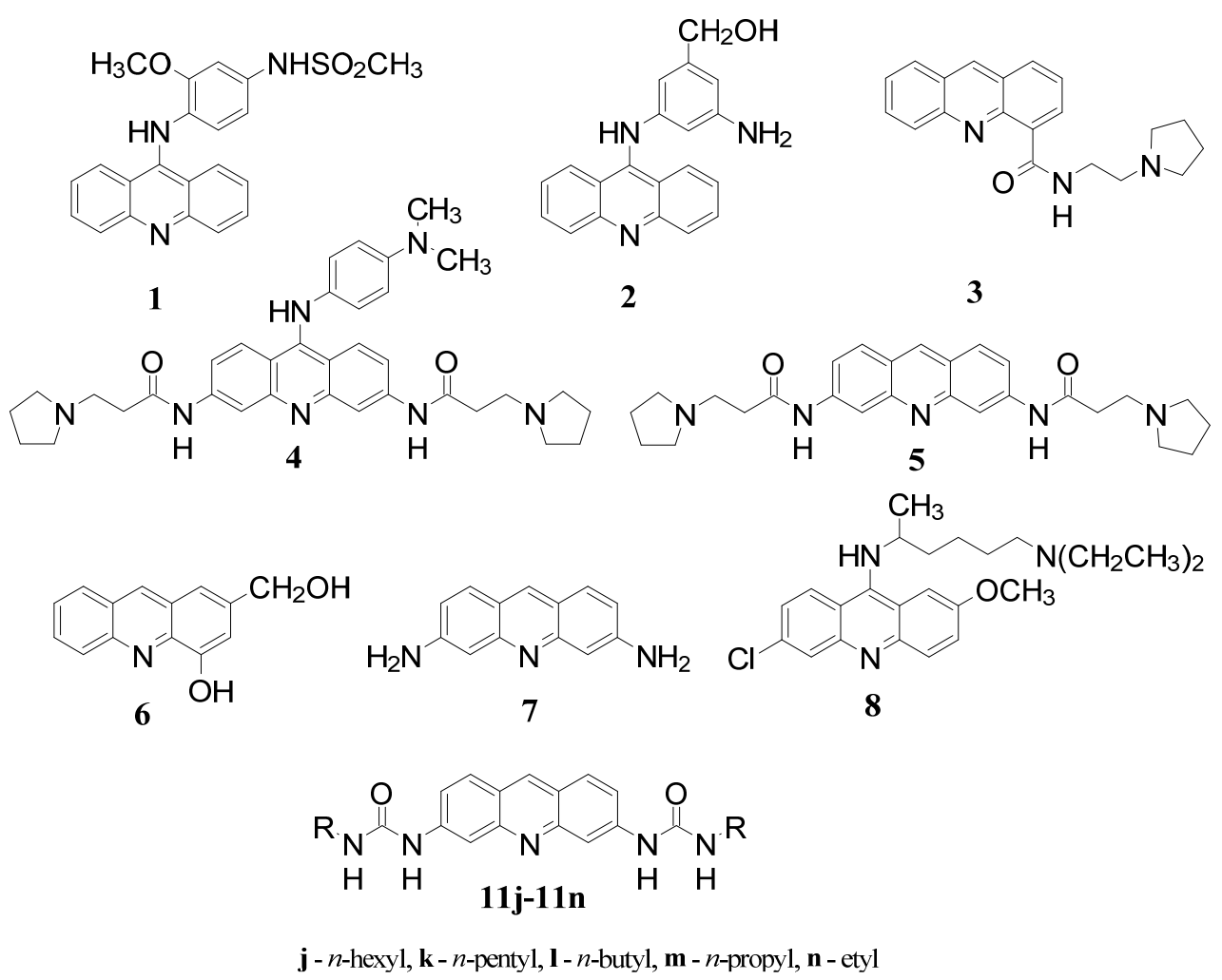

Figure 1. Acridine derivatives with biological activity.

Telomerase is a special type of DNA polymerase which maintains an elongation of a telomeric DNA shortening in tumor cells after each cell division cycle. Telomerase is an RNA reverse transcriptase that synthesizes telomeric DNA from an RNA template, thereby leading to the uncontrollable proliferation of malign cells [6]. Previous studies have shown that substituted acridines such as compounds 4 and 5 exhibit the ability to interact with the telomeric DNA, resulting in interesting cytostatic activities (Figure 1) [8,9].

Recently, the total synthesis of inubosine B6, an acridine alkaloid that initiates neuroregeneration, has been reported (Figure 1) [10]. Antimicrobial properties are another important category of biological activity displayed by acridine derivatives [11,12]. Proflavine $\mathbf{7}$ is the example of a typical antibacterial and antifungal agent, while quinacrine 8 exhibits antimalarial properties (Figure 1) [13].

In this study, we present a pharmacological model based on the entropy changes in the urea derivatives $\mathbf{1 1} \mathbf{j}-\mathbf{1 1 n}$ accompanying their DNA binding process. This pharmacological model could be used as a tool in the design of new urea-based intercalators with potential anticancer activity.

\section{Results and Discussion}

The stability of the intercalation between ctDNA and ureas $\mathbf{1 1} \mathbf{j}-\mathbf{1 1 n}$ (Figure 1) is highly dependent upon the length of the urea alkyl chains. Previous studies have observed that 
the enlargement of alkyl chains led to the reduced $K_{\mathrm{B}}$ value of the binding complex, and vice versa (Figure 2A) [14].

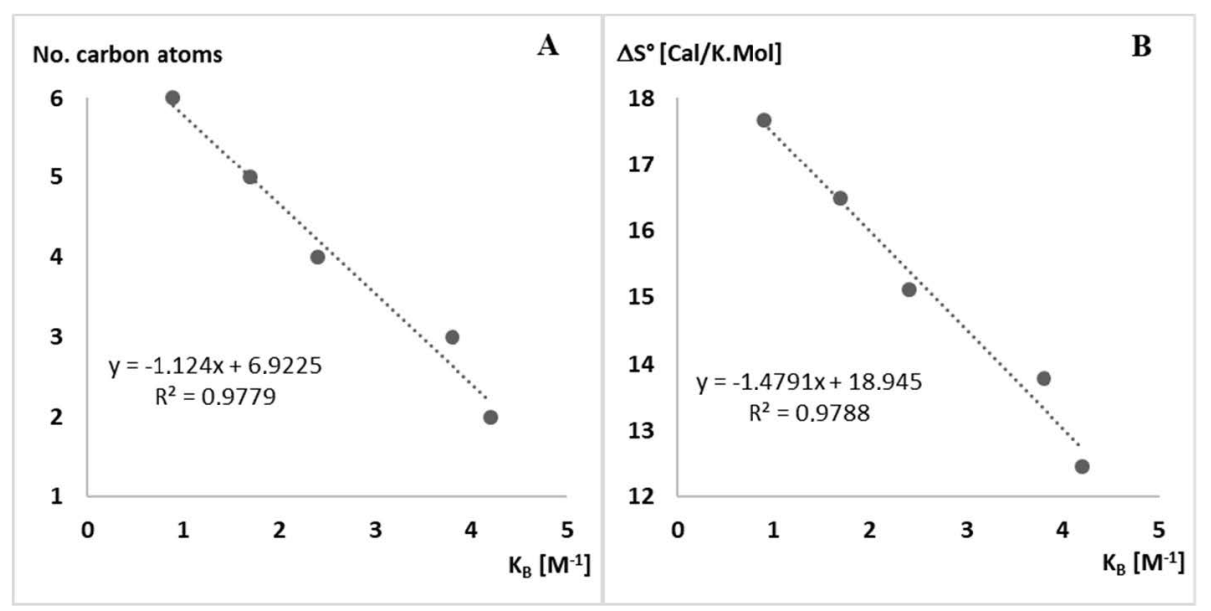

Figure 2. (A). Relationship of the binding constants $K_{\mathrm{B}}$ and the length of the alkyl chain of the urea derivatives. (B). Relationship of the binding constant $K_{\mathrm{B}}$ and the change in the standard entropy $\Delta S^{\circ}$. The binding constants $K_{\mathrm{B}} \times 10^{5}$ of the $c t$ DNA-urea $\mathbf{1 1} \mathbf{j}-\mathbf{1 1 n}$ intercalation complexes are given as a molar concentration. A value of the change in the standard entropy $\Delta S^{\circ}$ of urea derivatives 11j-11n given in cal.mol ${ }^{-1}$. $\mathrm{K}^{-1}$ was obtained using the PM7 method. Several carbon atoms define the number of carbons in the alkyl chain of the derivative. $\mathbf{1 1} \mathbf{j}-n$-hexyl, 11k- $n$-pentyl, 111- $n$-butyl, 11m-n-propyl, 11n-ethyl.

This finding prompted us to determine the relationship of the $K_{\mathrm{B}}$ values and the $\Delta S^{\circ}$ values for the urea derivatives $\mathbf{1 1 j}-\mathbf{1 1 n}$ (Figure 2B). The term $\Delta S^{\circ}$ reflects the structural features of the chains of specific urea derivatives, as is shown in Figure 2, and expresses the gap in the values of the standard entropy, $S^{\circ}$, obtained at the temperatures of $300 \mathrm{~K}$ and of $340 \mathrm{~K}$ using the PM7 method (Table 1). These findings will be discussed further within the framework of the urea-based molecular model design study.

Table 1. Physicochemical and biological data of urea derivatives $\mathbf{1 1} \mathbf{j}-\mathbf{1 1}$.

\begin{tabular}{|c|c|c|c|c|c|c|c|}
\hline $\mathbf{R}-{ }^{\mathbf{a}}$ & Urea $^{a}$ & $S^{\circ}{ }_{300 K}{ }^{b}$ & $S^{\circ}{ }_{340 K^{c}}$ & $\Delta S^{\circ \mathrm{d}}$ & $\log P^{\mathrm{e}}$ & $\mathrm{IC}_{50} \mathrm{f}$ & $K_{\mathrm{B}} \mathrm{g}$ \\
\hline & \multicolumn{5}{|c|}{ (Cal/K.Mol)(Cal/K.Mol)(Cal/K.Mol) } & $(\mu \mathrm{M})$ & $\left(10^{5}\right)$ \\
\hline n-Hexyl & $11 \mathrm{j}$ & 235.004 & 252.682 & 17.67 & 7.03 & 3.7 & 0.9 \\
\hline n-Pentyl & $11 \mathrm{k}$ & 215.063 & 231.541 & 16.47 & 6.02 & 13.3 & 1.7 \\
\hline n-Butyl & 111 & 197.441 & 212.554 & 15.11 & 5.01 & 11.5 & 2.4 \\
\hline n-Propyl & $11 \mathrm{~m}$ & 188.083 & 201.859 & 13.77 & 3.89 & 29.2 & 3.8 \\
\hline Ethyl & $11 \mathrm{n}$ & 172.036 & 184.490 & 12.45 & 2.88 & 60.1 & 4.2 \\
\hline
\end{tabular}

a: A substituent at the location of 3 and 6 of ureas 11j-11n. ${ }^{\text {b: }}$ Standard entropy for urea models 11j-11n at a temperature of $300 \mathrm{~K} .{ }^{c}$ : Standard entropy for urea models $\mathbf{1 1} \mathbf{j}-\mathbf{1 1 n}$ at a temperature of $340 \mathrm{~K}$. ${ }^{\mathrm{d}}$ : Gap between the standard entropy for urea models $\Delta S^{\circ}=S^{\circ}{ }_{340 \mathrm{~K}}-S^{\circ}{ }_{300 \mathrm{~K}} .{ }^{\mathrm{e}}:$ : Octanol-water partition coefficient as predicted by the web server molinspiration.com. ${ }^{\mathrm{f}}$ : Value of the constant $\mathrm{IC}_{50}$ determined against a HeLa cancer cell line. $\mathrm{g}$ : Value of the binding constant $K_{\mathrm{B}}$ for the complex of $c t$ DNA and ureas 11j-11n.

In order to predict the strength of the binding between the ligand and DNA, MM-GBSA (PBSA) calculations should be performed for specific intercalation complexes followed by a normal mode analysis to reveal the thermodynamic parameters of the binding process; more specifically, the binding free energy change and its enthalpic and entropic components [15]. Entropy changes are the consequence of the loss of degrees of freedom and enthalpy changes arise from conformation discrepancies when an intercalation complex is formed [6]. 
Furthermore, it is also necessary to consider the appropriate modes by which the ligand binds to DNA in order to obtain accurate results for the required calculations. However, this task is complicated by the complexity of the intermolecular interactions involved in the binding process. As a result, our study simplifies this process by employing an approach based on the following considerations.

We hypothesized that only the chains of ureas $\mathbf{1 1} \mathbf{j}-\mathbf{1 1 n}$ undergo structural changes during the formation of the complex. This idea arose from our expectation that the flexible alkyl chains would adapt to the macromolecule during the binding process rather than vice versa. We further hypothesized that a DNA lattice could undergo similar changes during the formation of complexes with urea derivatives $\mathbf{1 1} \mathbf{j}-\mathbf{1 1 n}$. Given such hypotheses, we could expect that the enthalpy changes in intercalation reactions across the entire series of urea derivatives 11j-11n would not differ substantially; therefore, $\Delta \Delta H_{\mathrm{rxn}}=\sim 0$.

On such a basis, it is possible to suggest that the stability of the binding complex depends substantially on the entropy changes in derivatives $\mathbf{1 1 j} \mathbf{- 1 1} \mathbf{n}$ which accompany an intercalation reaction. This can be rationalized using the above-mentioned relationship of $K_{\mathrm{B}}$ values versus the $\Delta S^{\circ}$ values (Figure 2B). In terms of structure, the $\Delta S^{\circ}$ value reflects the structural features of the chains of derivatives $\mathbf{1 1} \mathbf{j}-\mathbf{1 1}$. By extending this relationship as a prediction tool, the $\Delta S^{\circ}$ value could predict how strongly the urea model can bind to DNA.

Unexpectedly, the cytotoxicity $\left(\mathrm{IC}_{50}\right)$ of ureas $\mathbf{1 1} \mathbf{j}-\mathbf{1 1 n}$ was not found to increase with the increasing of the binding constant, $K_{\mathrm{B}}$, a finding which contradicts the hypothesis that DNA is the typical pharmacological target of such substances (Figure 3). A positive correlation was found for the relationship of cytotoxicity $\left(\mathrm{IC}_{50}\right)$ and lipophilicity $(\log P)$, which thereby reflects the fact that the ability of specific urea derivatives to penetrate the cell membrane is of equal importance in the anticancer activity as its ability to bind to DNA (Figure 4A). Analogously, the prediction of the lipophilicity of a given urea model may offer a useful estimate of its anticancer potential. The task which we addressed was, therefore, how to utilize the two opposing physicochemical properties of $\log P$ and $K_{\mathrm{B}}$ to predict the biological activity of a specific urea model.

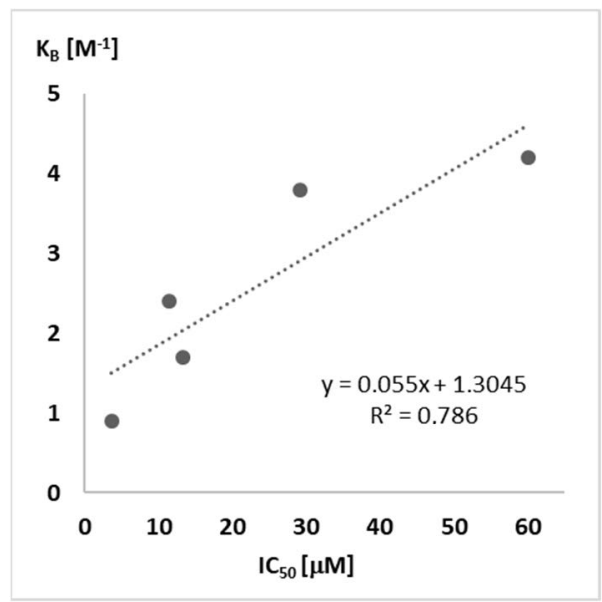

Figure 3. Relationship of the inhibition concentration $\mathrm{IC}_{50}$ and the binding constant $K_{\mathrm{B}}$. The binding constant $K_{\mathrm{B}} \times 10^{5}$ of the intercalation between ureas $\mathbf{1 1} \mathbf{j}-\mathbf{1 1} \mathbf{n}$ and $c t \mathrm{DNA}$ is given as a molar concentration. The value of the inhibition concentration $\mathrm{IC}_{50}$ of ureas $\mathbf{1 1} \mathbf{j}-\mathbf{1 1 n}$ against HeLa cancer cell lines is given as a micromolar concentration. 


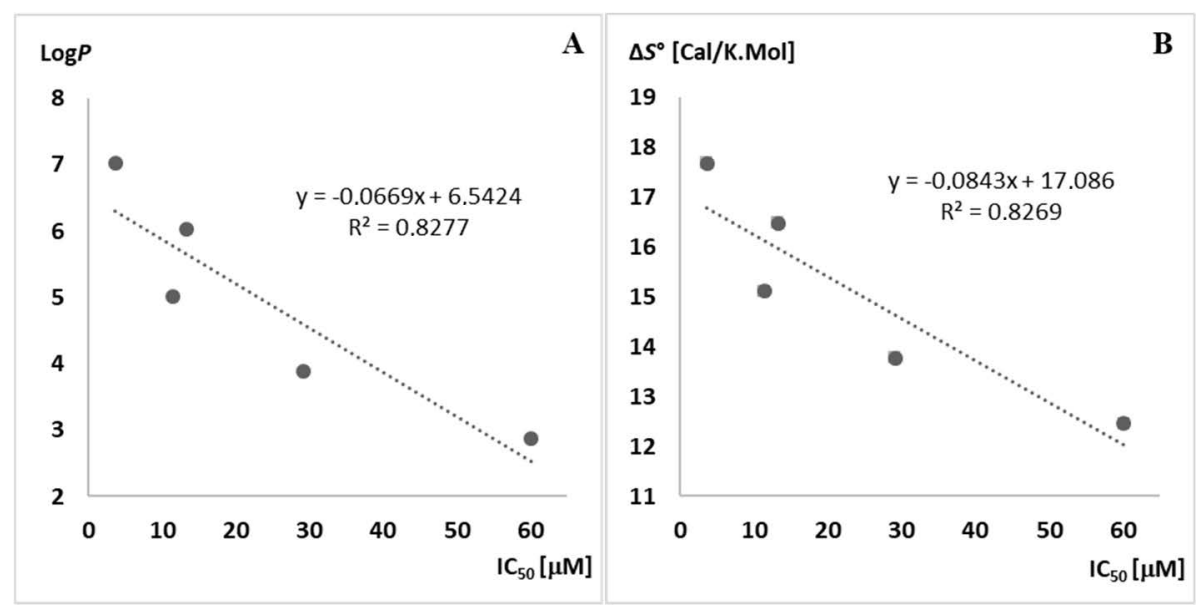

Figure 4. (A). Relationship of the inhibition concentration $\mathrm{IC}_{50}$ and the lipophilicity $\log P$. (B). Relationship of the inhibition concentration $\mathrm{IC}_{50}$ and the change in the standard entropy $\Delta S^{\circ}$. The value of the lipophilicity $\log P$ was determined using the Molinspiration software program (molinspiration.com). The value of the inhibition concentration $\mathrm{IC}_{50}$ of ureas $\mathbf{1 1} \mathbf{j}-\mathbf{1 1 n}$ against HeLa cancer cell lines is given as a micromolar concentration. The value of the change in the standard entropy $\Delta S^{\circ}$ of ureas 11j-11n given in cal.mol ${ }^{-1}$. $\mathrm{K}^{-1}$ was obtained using the PM7 method.

Bearing in mind the facts outlined above, it is clear that it would not be possible to design a urea-based model that exhibits both strong DNA binding capabilities and high levels of lipophilicity. One solution, therefore, would be to find a compromise structure, a molecule with sufficient lipophilicity to penetrate a cell membrane but which could still be able to form a stable complex with DNA. For this purpose, a pharmacological model was developed which utilized the relationship of $\mathrm{IC}_{50}$ versus $\log P$ and the relationship of $K_{\mathrm{B}}$ versus $\Delta S^{\circ}$ as prediction tools, both of which were discussed above. According to this model, only a determination of the value of $\log P$ and the value of $\Delta S^{\circ}$ would be required to determine the binding capacity and anticancer activity for a given urea model.

The pharmacological model is based on a scoring system that determines a specific range of score values which urea derivative models must achieve before they would be considered for synthesis. The score value is the sum of the $\log P$ value and the $\Delta S^{\circ}$ value of the urea model and the acceptable range for the derivative models was derived from the score values for the urea derivatives hexyl 111 and butyl 11n, compounds which display a reasonable range of biological activity (Figure 4).

In order to identify potential new urea-based intercalators with increased biological activity, quantum mechanics and cheminformatics were used to obtain the $\log P$ and $\Delta S^{\circ}$ values for specific urea models. Urea models I-XXIII were then modelled using ChemSketch software [16] (Figure 5).

The optimization of models I-XXIII were performed using the PM7 method and a post processing normal mode analysis provided the values of standard entropy, $S^{\circ}$ (Table 2). The calculations were performed using the MOPAC2016 software package, while the logP values for the model structures were obtained using Molinspiration online software [17,18]. The $\log \mathrm{P}$ and $\Delta S^{\circ}$ values were summed together in order to provide the score values of urea models I-XXIII (Table 2). Specific models would be considered as the leading structures if their score value fell within the range defined by the values of 20.1 and 24.7. Only models which featured six carbon atoms in their chains were synthesized: models VIII-XIV, XVII and XVIII (Figure 5). 


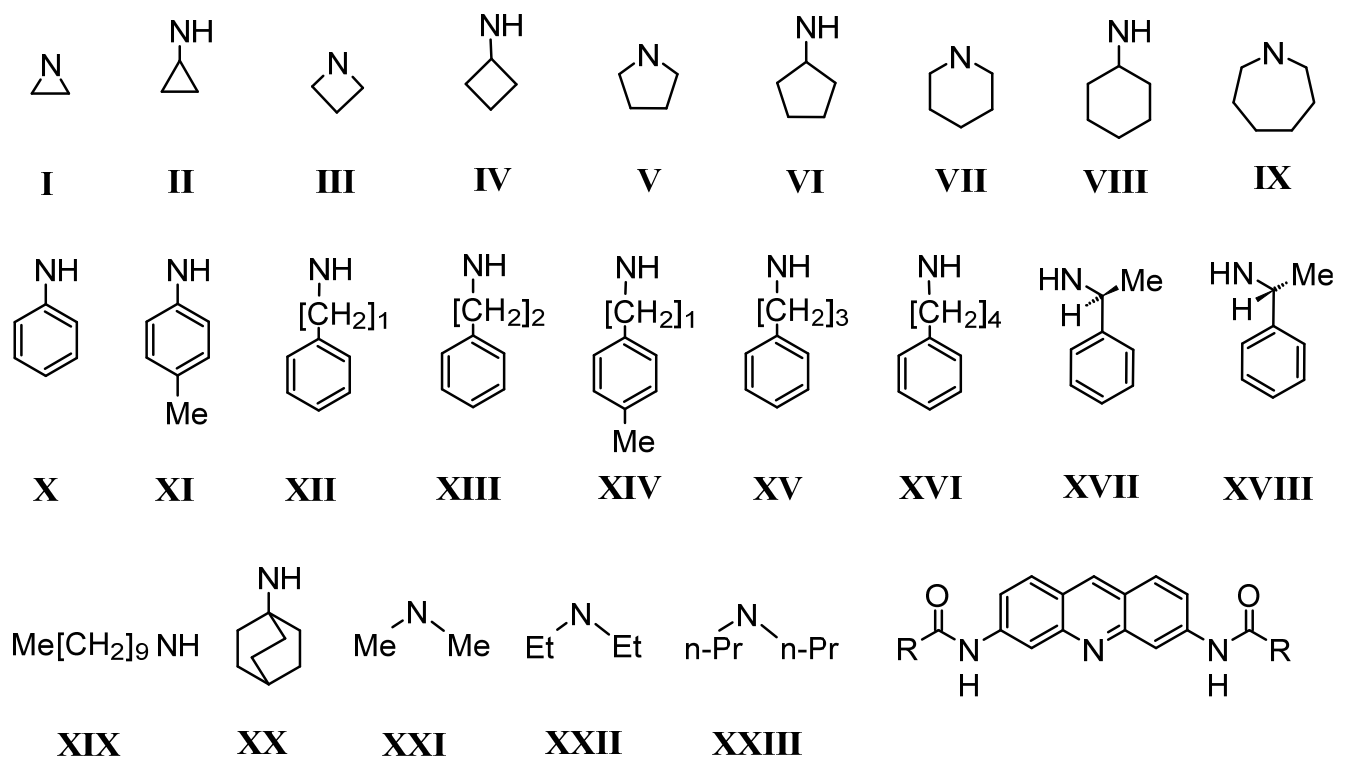

Figure 5. Urea models I-XXIII used within the molecular modeling study.

Table 2. Physicochemical data for urea models I-XXIII.

\begin{tabular}{|c|c|c|c|c|c|c|}
\hline$R-{ }^{a}$ & Model $^{a}$ & $S_{300 K}{ }^{b}$ & $S^{\circ}{ }_{340 \mathrm{~K}}{ }^{\mathrm{c}}$ & $\Delta S^{\circ \mathrm{d}}$ & $\log P^{\mathrm{e}}$ & Score $^{f}$ \\
\hline & & (Cal/K.Mol) & (Cal/K.Mol) & (Cal/K.Mol) & & \\
\hline Aziridine & $\mathrm{I}$ & 153.9 & 165.7 & 11.4 & 2.35 & 13.75 \\
\hline$N, N^{\prime}$-Dimethylamine & XXI & 171.9 & 184.5 & 12.5 & 1.84 & 14.34 \\
\hline Azetidine & III & 163.9 & 176.4 & 12.6 & 2.89 & 15.49 \\
\hline Cyklopropylamine & II & 176.9 & 189.8 & 12.9 & 2.86 & 15.76 \\
\hline Pyrolidine & $\mathrm{V}$ & 184.1 & 197.8 & 13.7 & 3.43 & 17.13 \\
\hline Cyklobutylamine & IV & 186.1 & 200.1 & 14 & 3.45 & 17.45 \\
\hline$N, N^{\prime}$-Diethylamine & XXII & 196.6 & 211.9 & 15.1 & 4.13 & 19.23 \\
\hline Piperidine & VII & 184.6 & 199.4 & 14.8 & 4.44 & 19.24 \\
\hline Cyklopentylamine & VI & 195.6 & 210.7 & 15.1 & 4.93 & 20.03 \\
\hline Aniline & $x$ & 177.7 & 192.2 & 14.5 & 5.53 & 20.03 \\
\hline Benzylamine & XII & 178.1 & 193.3 & 15.3 & 4.93 & 20.23 \\
\hline Azepane & IX & 194.6 & 210.6 & 16 & 5.45 & 21.45 \\
\hline Cyklohexylamine & VIII & 210.2 & 226.4 & 16.3 & 5.94 & 22.24 \\
\hline 4-Methylbenzylamine & XIV & 240.4 & 223.0 & 17.4 & 5.38 & 22.78 \\
\hline 4-Methylaniline & XI & 205.5 & 221.8 & 16.36 & 6.42 & 22.78 \\
\hline Phenylethylamine & XIII & 211.6 & 228.8 & 17.2 & 5.74 & 22.94 \\
\hline$(R / S)$-Methylethylamine & XVII/XVIII & 227.6 & 245.2 & 17.6 & 6.05 & 23.65 \\
\hline$N, N^{\prime}$-Dipropylamine & XXIII & 239.3 & 257.2 & 17.9 & 6.14 & 24.04 \\
\hline Phenylpropylamine & $\mathrm{XV}$ & 230.2 & 248.6 & 18.48 & 6.78 & 25.26 \\
\hline Phenylbutylamine & XVI & 235.5 & 255.2 & 19.73 & 7.32 & 27.05 \\
\hline Adamantylamine & $X X$ & 210.2 & 229.3 & 19.2 & 7.98 & 27.18 \\
\hline$n$-Dekylamine & XIX & 283.5 & 306.3 & 22.8 & 11.07 & 33.87 \\
\hline
\end{tabular}

${ }^{a}$ : A substituent at the location of 3 and 6 in the structure of the ureas models I-XXIII. ${ }^{b}$ : Standard entropy for urea models I-XXIII at a temperature of $300 \mathrm{~K}^{\mathrm{c}}{ }^{\mathrm{c}}$ : Standard entropy for urea models I-XXIII at a temperature of $340 \mathrm{~K}{ }^{\mathrm{d}}$ : Gap of the standard entropy for urea models $\Delta S^{\circ}=S^{\circ}{ }_{340 \mathrm{~K}}-S^{\circ}{ }_{300 \mathrm{~K}}{ }^{\text {e. }}$ : Octanol-water partition coefficient predicted by the molinspiration.com web server. ${ }^{\mathrm{f}}$ : Score value $=\Delta S^{\circ}+\log P$.

Models VIII-XIV, XVII and XVIII were used as the basis for the synthesis of urea derivatives 11a-11i, which were prepared following our previously published procedure (Scheme 1). The synthesis of 3,6-diisothiocyanatoacridine (9) was improved substantially, with the yield of the reaction increasing from the previous $53 \%$ to $83 \%$. Isothiocyanate 9 was purified through crystallization from toluene and was subsequently used in the synthesis of the related thioureas $\mathbf{1 0 a}-\mathbf{1 0} \mathbf{i}$ which were isolated as light yellow solids. The next step of the process was the preparation of the final urea derivatives 11a-11i through 
the reaction of the related thioureas with mesitylnitrile oxide in methanol. The synthesized derivatives were then used in the subsequent biological and biochemical experiments.<smiles></smiles><smiles></smiles>

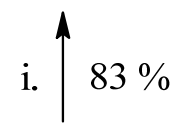

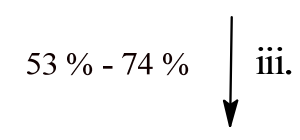<smiles>Nc1ccc2ccc(N)nc2c1</smiles><smiles></smiles>

i: $\mathrm{CSCl}_{2}, \mathrm{CHCl}_{3}, \mathrm{H}_{2} \mathrm{O}, \mathrm{Na}_{2} \mathrm{CO}_{3}, \mathrm{NaHCO}_{3}, 20 \mathrm{~min}$., $20^{\circ} \mathrm{C}$; ii: $\mathrm{R}_{-\mathrm{NH}_{2}}, \mathrm{CH}_{3} \mathrm{OH}, 3$ h., $20{ }^{\circ} \mathrm{C}$; iii: $\mathrm{MNO}, \mathrm{CH}_{3} \mathrm{OH}, 3$ h. -5 h., $20^{\circ} \mathrm{C}$.

Scheme 1. Synthesis of ureas 11a-11i.

Derivatives 11a-11i were subjected to in vitro screening on cancer cell lines conducted by the Developmental Therapeutic Program of the National Cancer Institute (NCI). A one-dose screen of each derivative against NCI-60 panels consisting of sixty human cancer cell lines was performed in order to identify the derivatives which exhibited the highest biological activity. On the basis of these results, ureas $\mathbf{1 1 b}, \mathbf{1 1} \mathrm{c}$ and $11 \mathrm{f}$ were selected for further evaluation of their growth inhibition activity. From the panel of sixty human cancer cell lines, a single cell line per tumor type was selected where the derivatives displayed the highest overall levels of cytostatic activity (Table 3). Urea derivative $\mathbf{1 1} \mathbf{j}$, the parent structure in the preceding molecular design study, was used as a standard to evaluate the pharmacological model presented herein.

Table 3. Growth inhibition concentration $\left(\mathrm{GI}_{50}\right)$ of ureas $\mathbf{1 1 b} \mathbf{1 1}$, $\mathbf{1 1 f}$ and $\mathbf{1 1}$, fluorouracil, cisplatin, amsacrine and doxorubicin against various human cancer cell lines. $\mathrm{GI}_{50}$ values are given as a micromolar concentration.

\begin{tabular}{|c|c|c|c|c|c|c|c|c|c|}
\hline & HL-60 & NCI-H522 & НCТ-116 & $\mathrm{U} 251$ & LOXIMVI & OVCAR-8 & RXF393 & DU-145 & HS578T \\
\hline & \multicolumn{9}{|c|}{$\mathrm{GI}_{50}(\mu \mathrm{M})$} \\
\hline Hexyl-11j & 0.26 & 0.32 & 0.36 & 0.65 & 0.22 & 0.45 & 1.41 & 2.00 & 0.63 \\
\hline Azepyl-11b & 0.23 & 1.58 & 0.44 & 0.54 & 1.41 & 1.70 & 0.22 & 1.74 & 0.78 \\
\hline Phenyl-11c & 1.20 & 1.58 & 0.23 & 0.98 & 0.47 & 1.15 & 1.48 & 2.40 & 1.51 \\
\hline Phenylethyl-11f & 0.26 & 0.32 & 0.35 & 0.74 & 0.20 & 0.81 & 1.32 & 1.23 & 0.28 \\
\hline Fluorouracil & 4.57 & 11.48 & 0.49 & 2.24 & 0.49 & 2.40 & 2.88 & 0.63 & 14.13 \\
\hline Cisplatin & 6.61 & 9.12 & 17.78 & 11.22 & 6.61 & 28.18 & 20.42 & 6.76 & 23.44 \\
\hline Amsacrine & 0.02 & 0.89 & 0.50 & 0.21 & 0.15 & 0.83 & 2.24 & nd * & nd * \\
\hline Doxorubicin & 0.08 & 0.03 & 0.03 & 0.03 & 0.03 & 0.07 & 0.08 & 0.07 & 0.13 \\
\hline
\end{tabular}

The results presented in Table 3 show clearly that ureas $\mathbf{1 1 b}, \mathbf{1 1 c}$, 11f and $\mathbf{1 1} \mathbf{j}$ did not display higher levels of cytostatic activity than doxorubicin. However, the ureas did exhibit promising anticancer activities that exceeded that of amsacrine, especially in the case of the HCT-166, RXF393 and NCI-H522 cancer cell lines (Table 3, Table S2). Against the selected cancer cell lines, urea derivatives $\mathbf{1 1 b}, \mathbf{1 1} \mathbf{c}, \mathbf{1 1 f}$ and $\mathbf{1 1} \mathbf{j}$ also displayed superior levels of biological activity than both fluorouracil and cisplatin.

In order to provide an overall view of the cytostatic activity of the urea derivatives, the $\mathrm{GI}_{50}$ values of each derivative for all cancer cell lines are listed in a decimal logarithmic form in the supplementary materials (Tables S1-S4). In summary, ureas 11b, 11c and 11f 
were found to be the most cytostatic against leukemia cell lines and moderate activity was also shown against colon cell lines (Table 4, Table S2).

Table 4. Decimal logarithm of growth inhibition concentration $\left(G_{50}\right)$ for ureas $\mathbf{1 1 b}, \mathbf{1 1 c}$, 11f and $\mathbf{1 1 j}$. $\mathrm{GI}_{50}$ values are given as a molar concentration.

\begin{tabular}{ccccc}
\hline Cancer Cell Line & Hexyl-11j & Azepyl-11b & Phenyl-11c & Phenylethyl-11f \\
\hline & \multicolumn{4}{c}{ Log10 $\mathbf{G I}_{\mathbf{5 0}} \mathbf{( M )}$} \\
\hline CCRF-CEM & -6.56 & -6.44 & -6.56 & -6.52 \\
HL-60(TB) & -6.59 & -6.64 & -5.92 & -6.58 \\
K-562 & -6.49 & -6.46 & -6.44 & -6.41 \\
MOLT-4 & -6.67 & -6.28 & -6.25 & -6.59 \\
RPMI-8226 & -5.79 & -6.5 & -5.27 & -5.65 \\
SR & -6.58 & -6.53 & -6.54 & -6.41 \\
COLO205 & -5.85 & -5.87 & -6.24 & -6.5 \\
HCC-2998 & -5.84 & -5.73 & -6.25 & -6.35 \\
HCT-116 & -6.44 & -6.36 & -6.63 & -6.46 \\
HCT-15 & -4.00 & -5.94 & -4.43 & -4.00 \\
HT29 & -5.65 & -6.37 & -5.72 & -5.86 \\
KM12 & -5.71 & -5.72 & -5.83 & -5.79 \\
SW-620 & -6.25 & -5.97 & -6.48 & -6.46 \\
\hline Average & $-\mathbf{6 . 0 3}$ & -6.22 & $-\mathbf{6 . 0 4}$ & $-\mathbf{6 . 1 2}$ \\
\hline
\end{tabular}

In order to determine the toxicity $\left(\mathrm{IC}_{50}\right)$ of the novel derivatives, the biological activity of ureas $\mathbf{1 1 b}, \mathbf{1 1 c}, \mathbf{1 1} \mathbf{f}$ and $\mathbf{1 1} \mathbf{j}$ were performed against immortalized foreskin fibroblasts (Table 5). The $\mathrm{IC}_{50}$ values obtained in the studies show that azepyl $\mathbf{1 1 \mathbf { b }}$ and phenylethyl 11f urea exhibited levels of cytotoxicity three orders of magnitude lower than their cytostatic activity. The highest level of cytotoxicity was displayed by hexyl urea $\mathbf{1 1} \mathbf{j}$, a level even greater than that of amsacrine after $48 \mathrm{~h}$ and $96 \mathrm{~h}$, whereas phenyl urea 11c was found to be more cytostatic. Figure 6 expresses the $\mathrm{IC}_{50}$ values in a decimal logarithm scale in order to allow a better comparison of the cytotoxicity of the proflavine ureas and amsacrine.

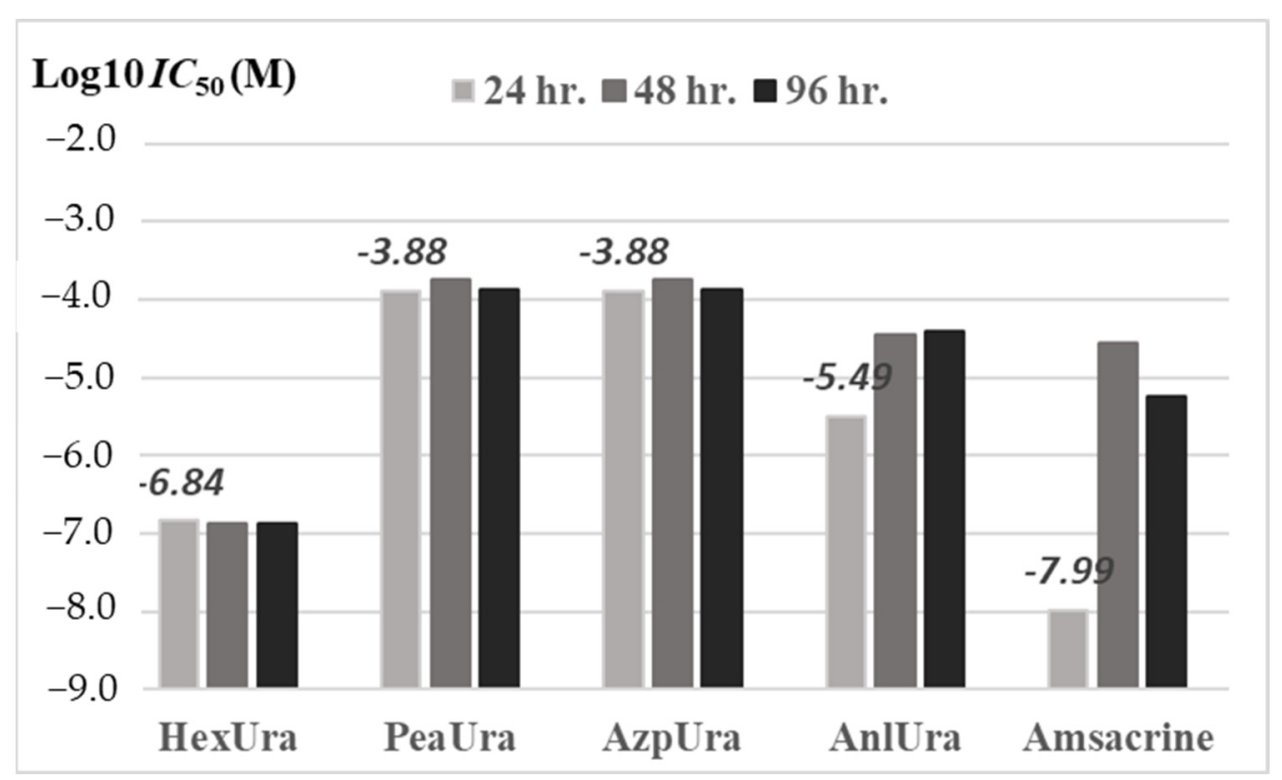

Figure 6. Decimal logarithm of the inhibition concentration $\left(\mathrm{IC}_{50}\right)$ of ureas $\mathbf{1 1 b}, \mathbf{1 1} \mathbf{c}, \mathbf{1 1 f}, \mathbf{1 1} \mathbf{j}$ and amsacrine against immortalised foreskin fibroblasts (BJ-5ta) after 24, 48 and $96 \mathrm{~h}$ determined by real-time cell analysis and dynamic monitoring of cell proliferation. $\mathrm{IC}_{50}$ values are given as a molar concentration. 
Table 5. Inhibition concentration ( $\mathrm{IC}_{50}$ ) of ureas $\mathbf{1 1 b}, \mathbf{1 1 c}, \mathbf{1 1 f}, \mathbf{1 1} \mathbf{j}$ and amsacrine against immortalised foreskin fibroblasts (BJ-5ta) after 24, 48 and $96 \mathrm{~h}$, determined by real-time cell analysis and dynamic monitoring of cell proliferation. $\mathrm{IC}_{50}$ values are given as a micromolar concentration.

\begin{tabular}{cccc}
\hline Urea & & $\begin{array}{l}\mathbf{I C}_{\mathbf{5 0}} \\
(\boldsymbol{\mu M})\end{array}$ & \\
\hline & $\mathbf{2 4} \mathbf{h}$ & $\mathbf{4 8 ~ h}$ & $\mathbf{9 6 ~ h}$ \\
\hline Hexyl-11j & 0.15 & 0.13 & 0.13 \\
Phenylethyl-11f & 131.00 & 180.00 & 137.00 \\
Azepyl-11b & 131.00 & 180.00 & 137.00 \\
Phenyl-11c & 3.20 & 34.80 & 38.50 \\
Amsacrine & 0.01 & 27.70 & 5.80 \\
\hline
\end{tabular}

\section{Materials and Methods}

\subsection{General Remarks}

All chemicals and reagents were of reagent grade. NMR spectra were measured on Varian VNMRS NMR and Varian Mercury Plus 400 FT NMR spectrometers at room temperature $(600,400 \mathrm{MHz}) . \delta$ values were referenced on a residual solvent signal as follows: for ${ }^{1} \mathrm{H}-\mathrm{DMSO}-d_{6}(2.49 \mathrm{ppm})$ and for ${ }^{13} \mathrm{C}-\mathrm{DMSO}-d_{6}$ (39.5 ppm). Reactions were monitored with thin-layer chromatography (TLC) using Silufol plates with detection at $254 \mathrm{~nm}$. Preparative column chromatography was performed using Aluminum oxide Merck 90 neutral (grain size $200 \mathrm{~nm}$ ). High-resolution mass spectra (HRMS) were recorded on a micrOTOF-QII quadrupole-time-of-flight mass spectrometer (Bruker Daltonics) with an electrospray ionization source. Optical rotations were determined using a P-2000 Jasco polarimeter. Melting points were recorded on a Koffler hot block and are presented uncorrected.

\subsection{Synthesis}

\subsubsection{Synthesis of 3,6-Diisothiocyanatoacridine (9)}

Proflavine hemisulfate hydrate (7) ( $300 \mathrm{mg}, 1.43 \mathrm{mmol})$, thiophogene $(0.22 \mathrm{~mL}, 2.87 \mathrm{mmol})$ and chloroform $(30 \mathrm{~mL})$ were poured into a flask to which $5 \mathrm{~mL}$ of the stock solution of sodium carbonate $\left(0.45 \mathrm{~g}\right.$ in $\left.25 \mathrm{~mL} \mathrm{H}_{2} \mathrm{O}\right)$ per 5 min was added while the mixture was shaken intensively. A solution of sodium bicarbonate $\left(1.50 \mathrm{~g}\right.$ in $\left.15 \mathrm{~mL} \mathrm{H}_{2} \mathrm{O}\right)$ was then added and the reaction mixture was stirred for $20 \mathrm{~min}$. In turn, an organic layer with the soluted product 9 was separated and dried over $\mathrm{CaCl}_{2}$. The crude product 9 was purified by flash chromatography on neutral aluminum oxide with chloroform as an eluent. The purified isotiocynate 9 was then crystalized from toluene $(50 \mathrm{~mL})$ with the addition of activated coal $(100 \mathrm{mg})$ at $80^{\circ} \mathrm{C}$. All physicochemical properties were in accordance with the previously published data [14].

\subsubsection{General Protocol for the Synthesis of Thioureas 10a-10k}

Amine $(2.0 \mathrm{mmol})$ was added to a heterogeneous solution of 3,6-diisothiocyanatoacridine (9) $(60 \mathrm{mg}, 0.20 \mathrm{mmol})$ in methanol $(1.50 \mathrm{~mL})$ [14]. The reaction mixture was stirred vigorously and the course of the reaction was monitored using TLC in which chloroform was used as an eluent. When the TLC result was negative in the presence of reactant 9 , diethylether was added and the resultant mixture was stirred for an additional two hours to maximize the precipitation of the product. The heterogeneous mixture was then filtered off and the crude product was washed with ethylacetate then with $n$-hexane in a funnel. The final product was crystalized from the DMF-methanol mixture.

$N, N^{\prime}$-Acridine-3,6-diylbis( $N^{\prime}$-cyclohexylthiourea) (10a, $\left.92 \mathrm{mg}, 91.3 \%\right)$. Yellow crystalline solid, $\mathrm{mp}>200{ }^{\circ} \mathrm{C}$ with decomposition. Thiourea was crystalized from the DMSOdiethyleter-methanol mixture. ${ }^{1} \mathrm{H}$ NMR $\left(600 \mathrm{MHz}, \mathrm{DMSO}-d_{6}\right) \delta 9.80(\mathrm{~s}, 2 \times \mathrm{NH}, 2 \mathrm{H}) 8.84(\mathrm{~s}$, $\mathrm{H} 9,1 \mathrm{H}) 8.39(\mathrm{~s}, \mathrm{H} 4, \mathrm{H} 5,2 \mathrm{H}), 8.03(\mathrm{~d}, J=7.8 \mathrm{~Hz}, 2 \times \mathrm{NH}, 2 \mathrm{H}), 8.00(\mathrm{~d}, J=9.1 \mathrm{~Hz}, \mathrm{H} 1, \mathrm{H} 8,2 \mathrm{H})$, $7.60(\mathrm{~d}, J=9.1 \mathrm{~Hz}, \mathrm{H} 2, \mathrm{H} 7,2 \mathrm{H}), 4.26-4.05(\mathrm{~m}, 2 \times \mathrm{NHCH}, 2 \mathrm{H}) 2.08-1.92\left(\mathrm{~m}, 4 \times \mathrm{NHCHCH}_{\mathrm{A}}\right.$, $4 \mathrm{H}), 1.84-1.65\left(\mathrm{~m}, 4 \times \mathrm{NHCHCH}_{2} \mathrm{CH}_{\mathrm{A}}, 4 \mathrm{H}\right) 1.65-1.52\left(\mathrm{~m}, 2 \times \mathrm{NHCHCH}_{2} \mathrm{CH}_{2} \mathrm{CH}_{\mathrm{A}}, \overline{2 \mathrm{H}}\right)$, 
1.47-1.26 (m, $\left.4 \times \mathrm{NHCHCH}_{\mathrm{B}}, 4 \mathrm{H}\right), 1.47-1.26\left(\mathrm{~m}, 4 \times \mathrm{NHCHCH}_{2} \mathrm{CH}_{\mathrm{B}}, 4 \mathrm{H}\right), 1.26-1.11(\mathrm{~m}$, $\left.2 \times \mathrm{NHCHCH}_{2} \mathrm{CH}_{2} \mathrm{CH}_{\mathrm{B}}, \overline{2 \mathrm{H}}\right) .{ }^{13} \mathrm{C} \mathrm{NMR}\left(150 \mathrm{MHz}, \mathrm{DMSO}-d_{6}\right) \delta \overline{179.0}(2 \times \mathrm{CS}), 149.4$ (C4a, C10a), 141.6 (C3, C6), 135.0 (C9), 128.5 (C1, C8), 122.6 (C8a, C9a), 122.5 (C2, C7), 115.6 $(\mathrm{C} 4, \mathrm{C} 5), 52.3(2 \times \mathrm{NHCH}), 31.8\left(4 \times \mathrm{NHCHCH}_{2}\right), 25.2\left(2 \times \mathrm{NHCHCH}_{2} \mathrm{CH}_{2} \mathrm{CH}_{2}\right), 24.5$ $\left(4 \times \mathrm{NHCHCH}_{2} \mathrm{CH}_{2}\right)$. HRMS (ESI): $m / z$ calculated for $\mathrm{C}_{27} \mathrm{H}_{33} \mathrm{~N}_{5} \mathrm{~S}_{2}[\mathrm{M}+\mathrm{H}]^{+} 492.22501$, found 492.22650 .

$N, N^{\prime}$-Acridine-3,6-diylbis(N'-(azepan-1-yl)thiourea) (10b, 96 mg, 95.2\%). Yellow crystalline solid, $\mathrm{mp}>200{ }^{\circ} \mathrm{C}$ with decomposition. Thiourea was crystallized from the DMSOdiethyleter-methanol mixture. ${ }^{1} \mathrm{H}$ NMR $\left(400 \mathrm{MHz}, \mathrm{DMSO}-d_{6}\right) \delta 9.38(\mathrm{~s}, 2 \times \mathrm{NH}, 2 \mathrm{H}), 8.88$ (s, H9, 1H), $7.97(\mathrm{~s}, \mathrm{H} 1, \mathrm{H} 8,2 \mathrm{H}), 7.85(\mathrm{~d}, J=9.1 \mathrm{~Hz}, \mathrm{H} 4, \mathrm{H} 5,2 \mathrm{H}), 7.70(\mathrm{~d}, J=9.1 \mathrm{~Hz}, \mathrm{H} 2$, $\mathrm{H} 7,2 \mathrm{H}), 4.01-3.80\left(\mathrm{~m}, 4 \times \mathrm{NCH}_{2}, 8 \mathrm{H}\right), 1.86-1.77\left(\mathrm{~m}, 4 \times \mathrm{NCH}_{2} \mathrm{CH}_{2}, 8 \mathrm{H}\right), 1.63-1.51(\mathrm{~m}$, $\left.4 \times \mathrm{NCH}_{2} \mathrm{CH}_{2} \mathrm{CH}_{2}, 8 \mathrm{H}\right) .{ }^{13} \mathrm{C}$ NMR $\left.\left(100 \mathrm{MHz}, \mathrm{DMSO}-d_{6}\right) \delta 180.6 \overline{(2} \times \mathrm{CS}\right), 149.1(\mathrm{C} 4 \mathrm{a}$, C10a), 143.2 (C3, $\overline{\mathrm{C} 6}$ ), 134.8 (C9), 126.9 (C1, C8), 125.9 (C2, C7), 123.3 (C8a, C9a), 119.9 (C4, C5), $50.0\left(4 \times \mathrm{NCH}_{2}\right), 26.9\left(4 \times \mathrm{NCH}_{2} \mathrm{CH}_{2}\right), 26.3\left(2 \times \mathrm{NCH}_{2} \mathrm{CH}_{2} \mathrm{CH}_{2}\right)$. HRMS (ESI): $m / z$ calculated for $\mathrm{C}_{27} \mathrm{H}_{33} \mathrm{~N}_{5} \mathrm{~S}_{2}[\mathrm{M}+\mathrm{H}]^{+} 492.22501$, found 492.22750 .

$N, N^{\prime}$-Acridine-3,6-diylbis( $N^{\prime}$-phenylthiourea) (10c, $\left.92 \mathrm{mg}, 93.5 \%\right)$. Yellow crystalline solid, $\mathrm{mp}>200^{\circ} \mathrm{C}$ with decomposition. Thiourea was crystalized from the DMSO-diethyletermethanol mixture. ${ }^{1} \mathrm{H}$ NMR $\left(600 \mathrm{MHz}, \mathrm{DMSO}-d_{6}\right) \delta 10.28$ (bs, $\left.2 \times \mathrm{NH}, 2 \mathrm{H}\right), 10.15$ (bs, $2 \times \mathrm{NH}, 2 \mathrm{H}), 8.91(\mathrm{~s}, \mathrm{H} 9,1 \mathrm{H}), 8.28(\mathrm{~s}, \mathrm{H} 4, \mathrm{H} 5,2 \mathrm{H}), 8.06(\mathrm{~d}, J=9.1 \mathrm{~Hz}, \mathrm{H} 1, \mathrm{H} 8,2 \mathrm{H}), 7.72(\mathrm{~d}$, $J=9.1 \mathrm{~Hz}, \mathrm{H} 2, \mathrm{H} 7,2 \mathrm{H}), 7.58-7.53\left(\mathrm{~m}, 2 \times\left(\mathrm{H}^{\prime}{ }^{\prime}, \mathrm{H} 6^{\prime}\right), 4 \mathrm{H}\right), 7.41-7.34\left(\mathrm{~m}, 2 \times\left(\mathrm{H}^{\prime}{ }^{\prime}, \mathrm{H}^{\prime}\right), 4 \mathrm{H}\right)$, 7.20-7.13 (m, $\left.2 \times \mathrm{H}^{\prime}{ }^{\prime}, 2 \mathrm{H}\right) .{ }^{13} \mathrm{C}$ NMR (150 MHz, DMSO- $\left.d_{6}\right) \delta 179.5(2 \times \mathrm{CS}), 149.3(\mathrm{C} 4 \mathrm{a}$, C10a), 141.5 (C3, C6), $139.3\left(2 \times \mathrm{C}^{\prime}\right), 135.2$ (C9), 128.6 ( $2 \times\left(\mathrm{C}^{\prime}, \mathrm{C}^{\prime}\right), 128.4$ (C1, C8), 124.7 $\left(2 \times \mathrm{C}^{\prime}\right), 123.7\left(2 \times\left(\mathrm{C}^{\prime}, \mathrm{C}^{\prime}\right)\right), 123.2(\mathrm{C} 2, \mathrm{C} 7), 123.1$ (C8a, C9a), 117.5 (C4, C5). HRMS (ESI): $m / z$ calculated for $\mathrm{C}_{27} \mathrm{H}_{21} \mathrm{~N}_{5} \mathrm{~S} 2[\mathrm{M}+\mathrm{H}]^{+} 480.13111$, found 480.13252 .

$N, N^{\prime}$-Acridine-3,6-diylbis(N'-benzylthiourea) (10d, $\left.100 \mathrm{mg}, 96.1 \%\right)$. Yellow crystalline solid, $\mathrm{mp}>200^{\circ} \mathrm{C}$ with decomposition. Thiourea was crystalized from the DMSO-diethyletermethanol mixture. ${ }^{1} \mathrm{H}$ NMR $\left(600 \mathrm{MHz}, \mathrm{DMSO}-d_{6}\right) \delta 10.08(\mathrm{~s}, 2 \times \mathrm{NH}, 2 \mathrm{H}), 8.88(\mathrm{~s}, \mathrm{H9}, 1 \mathrm{H})$, $8.58(\mathrm{t}, J=5.7 \mathrm{~Hz}, 2 \times \mathrm{NH}, 2 \mathrm{H}), 8.35(\mathrm{~s}, \mathrm{H} 4, \mathrm{H} 5,2 \mathrm{H}), 8.04(\mathrm{~d}, J=9.1 \mathrm{~Hz}, \mathrm{H1}, \mathrm{H} 8,2 \mathrm{H}), 7.61(\mathrm{~d}$, $J=9.1 \mathrm{~Hz}, \mathrm{H} 2, \mathrm{H} 7,2 \mathrm{H}), 7.40\left(\mathrm{~d}, J=7.3 \mathrm{~Hz}, 2 \times\left(\mathrm{H}^{\prime}, \mathrm{H6}^{\prime}\right), 4 \mathrm{H}\right), 7.44-7.34\left(\mathrm{~m}, 2 \times\left(\mathrm{H}^{\prime}, \mathrm{H}^{\prime}\right)\right.$, $4 \mathrm{H}), 7.32-7.26\left(\mathrm{~m}, 2 \times \mathrm{H}^{\prime}, 2 \mathrm{H}\right), 4.81\left(\mathrm{~d}, J=5.7 \mathrm{~Hz}, 2 \times \mathrm{NHCH}_{2}, 4 \mathrm{H}\right) .{ }^{13} \mathrm{C} \mathrm{NMR}(150 \mathrm{MHz}$, DMSO- $\left.d_{6}\right) \delta 180.6$ (CS), 149.4 (C4a, C10a), 141.3 (C3, C6), 138.7 (2 × C1'), 135.1 (C9), 128.7 $(\mathrm{C} 1, \mathrm{C} 8), 128.4\left(2 \times\left(\mathrm{C}^{\prime}, \mathrm{C} 5^{\prime}\right)\right), 127.6\left(2 \times\left(\mathrm{C}^{\prime}, \mathrm{C}^{\prime}\right)\right), 127.0\left(2 \times \mathrm{C}^{\prime}\right), 125.9(\mathrm{C} 8 \mathrm{a}, \mathrm{C} 9 \mathrm{a}), 122.8$ $(\mathrm{C} 2, \mathrm{C} 7), 116.6(\mathrm{C} 4, \mathrm{C} 5), 47.3\left(2 \times \mathrm{NHCH}_{2}\right)$. HRMS (ESI): $m / z$ calculated for $\mathrm{C}_{29} \mathrm{H}_{25} \mathrm{~N}_{5} \mathrm{~S}_{2}$ $[\mathrm{M}+\mathrm{H}]^{+}$508.16241, found 508.16480.

N,N'-Acridine-3,6-diylbis( $N^{\prime}$-(4-methylphenyl)thiourea) (10e, $\left.92 \mathrm{mg}, 88.4 \%\right)$. Yellow crystalline solid, $\mathrm{mp}>120^{\circ} \mathrm{C}$ with decomposition. Thiourea was crystalized from the DMSOdiethyleter-methanol mixture.1H NMR (400 MHz, DMSO- $\left.d_{6}\right) \delta 10.19(\mathrm{~s}, 2 \times \mathrm{NH}, 2 \mathrm{H})$, $10.04(\mathrm{~s}, 2 \times \mathrm{NH}, 2 \mathrm{H}), 8.89(\mathrm{~s}, \mathrm{H} 9,1 \mathrm{H}), 8.26(\mathrm{~s}, \mathrm{H} 4, \mathrm{H} 5,2 \mathrm{H}), 8.04(\mathrm{~d}, J=9.1 \mathrm{~Hz}, \mathrm{H} 1, \mathrm{H} 8,2 \mathrm{H})$, $7.71(\mathrm{~d}, J=9.1 \mathrm{~Hz}, \mathrm{H} 2, \mathrm{H} 7,2 \mathrm{H}), 7.39\left(\mathrm{~d}, J=7.3 \mathrm{~Hz}, 2 \times\left(\mathrm{H}^{\prime}, \mathrm{H} 6^{\prime}\right), 4 \mathrm{H}\right), 7.17(\mathrm{~d}, J=7.3 \mathrm{~Hz}$, $\left.2 \times\left(\mathrm{H}^{\prime}, \mathrm{H} 5^{\prime}\right), 4 \mathrm{H}\right), 2.29\left(\mathrm{~s}, 2 \times \mathrm{CH}_{3}, 6 \mathrm{H}\right) .{ }^{13} \mathrm{C}$ NMR $\left(100 \mathrm{MHz}, \mathrm{DMSO}-d_{6}\right) \delta 179.7(2 \times \mathrm{CS})$, 149.4 (C4a, C10a), 141.8 (C3, C6), 136.8 ( $\left.2 \times \mathrm{Cl}^{\prime}\right), 135.4$ ( $\left.2 \times \mathrm{C}^{\prime}\right), 134.3$ (C9), 129.2 (C1, C8), $128.5\left(2 \times\left(\mathrm{C}^{\prime}, \mathrm{C}^{\prime}\right)\right), 124.1\left(2 \times\left(\mathrm{C}^{\prime}, \mathrm{C} 6^{\prime}\right)\right), 123.4(\mathrm{C} 2, \mathrm{C} 7), 123.2(\mathrm{C} 8 \mathrm{a}, \mathrm{C} 9 \mathrm{a}), 117.6$ (C4, C5), $20.7\left(2 \times \mathrm{CH}_{3}\right)$. HRMS (ESI): $m / z$ calculated for $\mathrm{C}_{29} \mathrm{H}_{25} \mathrm{~N}_{5} \mathrm{~S}_{2}[\mathrm{M}+\mathrm{H}]^{+} 508.16241$, found 508.16475 .

N,N'-Acridine-3,6-diylbis(N'-(2-phenylethyl)thiourea) (10f, $100 \mathrm{mg}, 91.1 \%)$. Yellow crystalline solid, $\mathrm{mp}>180^{\circ} \mathrm{C}$ with decomposition. Thiourea was crystalized from the DMSOdiethyleter-methanol mixture. ${ }^{1} \mathrm{H}$ NMR $\left(400 \mathrm{MHz}, \mathrm{DMSO}-d_{6}\right) \delta 10.02(\mathrm{bs}, 2 \times \mathrm{NH}, 2 \mathrm{H})$, 8.86 (s, H9, 1H), 8.29 (s, H4, H5, 2H), 8.25-8.14 (m, $2 \times \mathrm{NH}, 2 \mathrm{H}), 8.01(\mathrm{~d}, J=9.1 \mathrm{~Hz}$, $\mathrm{H} 1, \mathrm{H} 8,2 \mathrm{H}), 7.55$ (d, J = 9.1 Hz, H2, H7, 2H), 7.39-7.28 (m, $2 \times\left(\mathrm{H}^{\prime}, \mathrm{H}^{\prime}\right), 2 \times\left(\mathrm{H}^{\prime}\right.$, $\left.\left.\mathrm{H}^{\prime}\right), 8 \mathrm{H}\right), 7.27-7.21\left(\mathrm{~m}, 2 \times \mathrm{H} 4^{\prime}, 2 \mathrm{H}\right), 3.84-3.74\left(\mathrm{~m}, 2 \times \mathrm{NHCH}_{2}, 4 \mathrm{H}\right), 2.95(\mathrm{t}, J=6.4 \mathrm{~Hz}$,

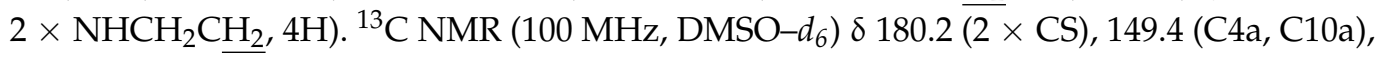
$141.2(\mathrm{C} 3, \mathrm{C} 6), 139.3\left(2 \times \mathrm{C}^{\prime}\right), 135.0(\mathrm{C} 9), 128.7\left(2 \times\left(\mathrm{C}^{\prime}, \mathrm{C}^{\prime}\right),(\mathrm{C} 1, \mathrm{C} 8)\right), 128.5\left(2 \times\left(\mathrm{C} 3^{\prime}\right.\right.$, $\left.\mathrm{C}^{\prime}\right), 126.2\left(2 \times \mathrm{C}^{\prime}\right), 122.8(\mathrm{C} 8 \mathrm{a}, \mathrm{C} 9 \mathrm{a}), 122.6(\mathrm{C} 2, \mathrm{C} 7), 116.4(\mathrm{C} 4, \mathrm{C} 5), 45.5\left(2 \times \mathrm{NHCH}_{2} \mathrm{CH}_{2}\right)$, 
$34.3\left(2 \times \mathrm{NHCH}_{2} \mathrm{CH}_{2}\right)$. HRMS (ESI): $m / z$ calculated for $\mathrm{C}_{31} \mathrm{H}_{29} \mathrm{~N}_{5} \mathrm{~S}_{2}[\mathrm{M}+\mathrm{H}]^{+} 536.19371$, found 536.19362 .

$N, N^{\prime}$-Acridine-3,6-diylbis( $\left.N^{\prime}-(2-m e t h y l b e n z y l) t h i o u r e a\right)(10 \mathrm{~g}, 104 \mathrm{mg}, 94.7 \%)$. Yellow crystalline solid, $\mathrm{mp}>180^{\circ} \mathrm{C}$ with decomposition. Thiourea was crystalized from the DMSO-diethyleter-methanol mixture. ${ }^{1} \mathrm{H}$ NMR $\left(400 \mathrm{MHz}, \mathrm{DMSO}-d_{6}\right) \delta 10.04$ (bs, $2 \times \mathrm{NH}$, $2 \mathrm{H}), 8.87(\mathrm{~s}, \mathrm{H} 9,1 \mathrm{H}), 8.60-8.46(\mathrm{~m}, 2 \times \mathrm{NH}, 2 \mathrm{H}), 8.35(\mathrm{~s}, \mathrm{H} 4, \mathrm{H} 5,2 \mathrm{H}), 8.03(\mathrm{~d}, J=9.1 \mathrm{~Hz}$, $\mathrm{H1}, \mathrm{H} 8,2 \mathrm{H}), 7.61(\mathrm{~d}, J=9.1 \mathrm{~Hz}, \mathrm{H} 2, \mathrm{H7}, 2 \mathrm{H}), 7.29\left(\mathrm{~d}, J=7.3 \mathrm{~Hz}, 2 \times\left(\mathrm{H} 2^{\prime}, \mathrm{H6} 6^{\prime}\right), 4 \mathrm{H}\right), 7.18(\mathrm{~d}$, $\left.J=7.3 \mathrm{~Hz}, 2 \times\left(\mathrm{H}^{\prime}, \mathrm{H}^{\prime}\right), 4 \mathrm{H}\right), 4.75\left(\mathrm{~d}, J=5.7 \mathrm{~Hz}, 2 \times \mathrm{NHCH}_{2}, 4 \mathrm{H}\right), 2.30\left(\mathrm{~s}, 2 \times \mathrm{CH}_{3}, 6 \mathrm{H}\right)$. ${ }^{13} \mathrm{C}$ NMR $\left(100 \mathrm{MHz}, \mathrm{DMSO}-d_{6}\right) \delta 180.5(2 \times \mathrm{CS}), 149.4$ (C4a, C10a), 141.3 (C3, C6), 136.1 $\left(2 \times \mathrm{C}^{\prime}\right), 135.5\left(2 \times \mathrm{C}^{\prime}\right), 135.1(\mathrm{C} 9), 128.9\left(2 \times\left(\mathrm{C}^{\prime}, \mathrm{C}^{\prime}\right), 128.7(\mathrm{C} 1, \mathrm{C} 8), 127.6\left(2 \times\left(\mathrm{C}^{\prime}\right.\right.\right.$, C6'), 122.9 (C8a, C9a), 122.8 (C2, C7), 116.5 (C4, C5), $47.0\left(2 \times \mathrm{NHCH}_{2}\right), 20.7\left(2 \times \mathrm{CH}_{3}\right)$. HRMS (ESI): $m / z$ calculated for $\mathrm{C}_{31} \mathrm{H}_{29} \mathrm{~N}_{5} \mathrm{~S}_{2}[\mathrm{M}+\mathrm{H}]^{+} 536.19371$, found 536.19574 .

$N, N^{\prime}$-Acridine-3,6-diylbis( $N^{\prime}-[(1 S)$-1-phenylethyl]thiourea) (10h, $40 \mathrm{mg}, 36.4 \%)$. Yellow crystalline solid, $\mathrm{mp}>200{ }^{\circ} \mathrm{C}$ with decomposition. Thiourea was crystalized from the diethyleter- $n$-hexane mixture. ${ }^{1} \mathrm{H}$ NMR $\left(600 \mathrm{MHz}, \mathrm{DMSO}-d_{6}\right) \delta 9.89(\mathrm{~s}, 2 \times \mathrm{NH}, 2 \mathrm{H}), 8.85$ (s, H9, 1H), 8.62-8.51 (m, $2 \times \mathrm{NH}, 2 \mathrm{H}), 8.41(\mathrm{~s}, \mathrm{H} 4, \mathrm{H} 5,2 \mathrm{H}), 8.01(\mathrm{~d}, J=9.1 \mathrm{~Hz}, \mathrm{H} 1, \mathrm{H} 8$, $2 \mathrm{H}), 7.61(\mathrm{~d}, J=9.1 \mathrm{~Hz}, \mathrm{H} 2, \mathrm{H} 7,2 \mathrm{H}), 7.42\left(\mathrm{~d}, J=7.3 \mathrm{~Hz}, 2 \times\left(\mathrm{H}^{\prime}, \mathrm{H}^{\prime}\right), 4 \mathrm{H}\right), 7.46-7.33$ $\left(\mathrm{m}, 2 \times\left(\mathrm{H}^{\prime}, \mathrm{H}^{\prime}\right), 4 \mathrm{H}\right), 7.31-7.24\left(\mathrm{~m}, 2 \times \mathrm{H}^{\prime}, 2 \mathrm{H}\right), 5.67-5.51(\mathrm{~m}, 2 \times \mathrm{NHCH}, 2 \mathrm{H}), 1.52$ $\left(\mathrm{d}, J=7.0 \mathrm{~Hz}, 2 \times \mathrm{CH}_{3}, 6 \mathrm{H}\right) .{ }^{13} \mathrm{C}$ NMR $\left(150 \mathrm{MHz}, \mathrm{DMSO}-d_{6}\right) \delta 179.5(2 \times \mathrm{CS}), 149.4(\mathrm{C} 4 \mathrm{a}$, C10a), $143.7\left(2 \times \mathrm{C1}^{\prime}\right), 141.6(\mathrm{C} 3, \mathrm{C} 6), 135.0$ (C9), 128.5 (C1, C8), $128.4\left(2 \times\left(\mathrm{C}^{\prime}, \mathrm{C} 5^{\prime}\right)\right)$, $126.9\left(2 \times \mathrm{C}^{\prime}\right), 126.3\left(2 \times\left(\mathrm{C}^{\prime}, \mathrm{C}^{\prime}\right)\right), 122.7(\mathrm{C} 8 \mathrm{a}, \mathrm{C} 9 \mathrm{a}), 122.6(\mathrm{C} 2, \mathrm{C} 7), 116.1(\mathrm{C} 4, \mathrm{C} 5)$, $52.7(2 \times \mathrm{NH} \underline{\mathrm{CH}}), 21.9\left(2 \times \mathrm{CH}_{3}\right)$. [ $\left.\alpha\right] D_{20}=+33.3$ (c 0.06, Methanol). HRMS (ESI): $\mathrm{m} / z$ calculated for $\mathrm{C}_{31} \mathrm{H}_{29} \mathrm{~N}_{5} \mathrm{~S}_{2}[\mathrm{M}+\mathrm{H}]^{+}$536.19371, found 536.19405 .

$N, N^{\prime}$-Acridine-3,6-diylbis( $N^{\prime}-[(1 R)-1$-phenylethyl]thiourea) (10i, $37 \mathrm{mg}, 33.7 \%)$. Yellow crystalline solid, $\mathrm{mp}>200{ }^{\circ} \mathrm{C}$ with decomposition. Thiourea was crystalized from the diethyleter- $n$-hexane mixture. ${ }^{1} \mathrm{H}$ NMR $\left(400 \mathrm{MHz}, \mathrm{DMSO}-d_{6}\right) \delta 9.89(\mathrm{~s}, 2 \times \mathrm{NH}, 2 \mathrm{H}), 8.85$ (s, H9, 1H), 8.62-8.51 (m, $2 \times \mathrm{NH}, 2 \mathrm{H}), 8.41(\mathrm{~s}, \mathrm{H} 4, \mathrm{H} 5,2 \mathrm{H}), 8.01(\mathrm{~d}, J=9.1 \mathrm{~Hz}, \mathrm{H} 1, \mathrm{H} 8$, $2 \mathrm{H}), 7.61(\mathrm{~d}, J=9.1 \mathrm{~Hz}, \mathrm{H} 2, \mathrm{H} 7,2 \mathrm{H}), 7.42\left(\mathrm{~d}, J=7.3 \mathrm{~Hz}, 2 \times\left(\mathrm{H}^{\prime}, \mathrm{H}^{\prime}\right), 4 \mathrm{H}\right), 7.46-7.33$ $\left(\mathrm{m}, 2 \times\left(\mathrm{H}^{\prime}, \mathrm{H}^{\prime}\right), 4 \mathrm{H}\right), 7.31-7.24\left(\mathrm{~m}, 2 \times \mathrm{H} 4^{\prime}, 2 \mathrm{H}\right), 5.67-5.51(\mathrm{~m}, 2 \times \mathrm{NHCH}, 2 \mathrm{H}), 1.52$ $\left(\mathrm{d}, J=7.0 \mathrm{~Hz}, 2 \times \mathrm{CH}_{3}, 6 \mathrm{H}\right) .{ }^{13} \mathrm{C}$ NMR $\left(100 \mathrm{MHz}, \mathrm{DMSO}-d_{6}\right) \delta 179.5(2 \times \mathrm{CS}), 149.4(\mathrm{C} 4 \mathrm{a}$, C10a), 143.7 ( $\left.2 \times \mathrm{C}^{\prime}\right), 141.6(\mathrm{C} 3, \mathrm{C} 6), 135.0$ (C9), 128.5 (C1, C8), $128.4\left(2 \times\left(\mathrm{C}^{\prime}, \mathrm{C} 5^{\prime}\right)\right)$, $126.9\left(2 \times \mathrm{C}^{\prime}\right), 126.3\left(2 \times\left(\mathrm{C}^{\prime}, \mathrm{C}^{\prime}\right)\right), 122.7(\mathrm{C} 8 \mathrm{a}, \mathrm{C} 9 \mathrm{a}), 122.6(\mathrm{C} 2, \mathrm{C} 7), 116.1(\mathrm{C} 4, \mathrm{C} 5)$, $52.7(2 \times \mathrm{NHCH}), 21.9\left(2 \times \mathrm{CH}_{3}\right) .[\alpha] D_{20}=-33.3$ (c 0.06, Methanol). HRMS (ESI): $m / z$ calculated for $\mathrm{C}_{31} \mathrm{H}_{29} \mathrm{~N}_{5} \mathrm{~S}_{2}[\mathrm{M}+\mathrm{H}]^{+}$536.19371, found 536.19574.

$N, N^{\prime}$-Acridine-3,6-diylbis(N'-hexylthiourea) $(\mathbf{1 0 j}, 90 \mathrm{mg}, 90.8 \%)$. All physicochemical properties were in accordance with previously published data [14].

\subsubsection{General Protocol for the Synthesis of the Ureas 11a-111}

MNO (2.30 mol\%) was added to a heterogeneous mixture of urea $(50 \mathrm{mg})$ in methanol $(3 \mathrm{~mL})$ [14]. The reaction mixture was stirred vigorously in dark conditions for $3-5 \mathrm{~h}$. The course of the reaction was monitored using TLC with a methanol-ammonium hydroxide mixture at a volume ratio of 1:10 as an eluent. The crude product was then filtered off and washed with methanol $(1 \mathrm{~mL})$, diethyleter $(1 \mathrm{~mL})$ and ethylacetate $(1 \mathrm{~mL})$.

$N, N^{\prime}$-Acridine-3,6-diylbis( $N^{\prime}$-cyclohexylurea) (11a, $\left.35 \mathrm{mg}, 74.7 \%\right)$. Yellow crystalline solid, $\mathrm{mp}>200{ }^{\circ} \mathrm{C}$ with decomposition. Thiourea was crystalized from the DMSO-diethyletermethanol mixture. ${ }^{1} \mathrm{H}$ NMR $\left(600 \mathrm{MHz}, \mathrm{DMSO}-d_{6}\right) \delta 8.75(\mathrm{~s}, 2 \times \mathrm{NH}, 2 \mathrm{H}), 8.69(\mathrm{~s}, \mathrm{H} 9,1 \mathrm{H})$, $8.12(\mathrm{~s}, \mathrm{H} 4, \mathrm{H} 5,2 \mathrm{H}), 7.91$ (d, J = 9.1 Hz, H1, H8, 2H), $7.43(\mathrm{~d}, J=9.1 \mathrm{~Hz}, \mathrm{H} 2, \mathrm{H} 7,2 \mathrm{H}), 6.28$ $(\mathrm{d}, J=7.8 \mathrm{~Hz}, 2 \times \mathrm{NH}, 2 \mathrm{H}), 3.60-3.47(\mathrm{~m}, 2 \times \mathrm{NHC} \underline{\mathrm{H}}, 2 \mathrm{H}), 1.91-1.76\left(\mathrm{~m}, 4 \times \mathrm{NHCHCH}_{\mathrm{A}}\right.$, $4 \mathrm{H}), 1.76-1.62\left(\mathrm{~m}, 4 \times \mathrm{NHCHCH}_{2} \mathrm{CH}_{\mathrm{A}}, 4 \mathrm{H}\right), 1.62-1.45\left(\mathrm{~m}, 2 \times \mathrm{NHCHCH}_{2} \mathrm{CH}_{2} \mathrm{CH}_{\mathrm{A}}\right.$, $2 \mathrm{H}), 1.43-1.27\left(\mathrm{~m}, 4 \times \mathrm{NHCHCH}_{2} \mathrm{CH}_{\mathrm{B}}, 4 \mathrm{H}\right), 1.27-1.05\left(\mathrm{~m}, 2 \times \mathrm{NHCHCH}_{2} \mathrm{CH}_{2} \mathrm{CH}_{\mathrm{B}}, 2 \mathrm{H}\right)$, 1.27-1.05 (m, $\left.4 \times \mathrm{NHCHCH}_{\mathrm{B}}, 4 \mathrm{H}\right) .{ }^{13} \mathrm{C} \mathrm{NMR}\left(150 \mathrm{MHz}, \mathrm{DMSO}-d_{6}\right) \delta 154.2(2 \times \mathrm{CO}), 150.1$ (C4a, C10a), 142.1 (C3, C6), 134.9 (C9), 129.0 (C1, C8), 121.2 (C8a, C9a), 119.4 (C2, C7), 110.8 $(\mathrm{C} 4, \mathrm{C} 5), 47.7(2 \times \mathrm{NHCH}), 32.9\left(4 \times \mathrm{NHCHCH}_{2}\right), 25.3\left(2 \times \mathrm{NHCHCH}_{2} \mathrm{CH}_{2} \mathrm{CH}_{2}\right), 24.4$ 
(4 $\times \mathrm{NHCHCH}_{2} \mathrm{CH}_{2}$ ). HRMS (ESI): $m / z$ calculated for $\mathrm{C}_{27} \mathrm{H}_{33} \mathrm{~N}_{5} \mathrm{O}_{2}[\mathrm{M}+\mathrm{H}]^{+} 460.27070$, found 460.27032 .

$N, N^{\prime}$-Acridine-3,6-diylbis(N'-(azepan-1-yl)urea) (11b, $\left.30 \mathrm{mg}, 53.5 \%\right)$. Yellow crystalline solid, $\mathrm{mp}>200{ }^{\circ} \mathrm{C}$ with decomposition. Thiourea was crystalized from the DMSOdiethyleter-methanol mixture. ${ }^{1} \mathrm{H}$ NMR $\left(600 \mathrm{MHz}, \mathrm{DMSO}-d_{6}\right) \delta 8.72(\mathrm{~s}, \mathrm{H} 9,1 \mathrm{H}), 8.57$ $(\mathrm{s}, 2 \times \mathrm{NH}, 2 \mathrm{H}), 8.19(\mathrm{~s}, \mathrm{H} 4, \mathrm{H} 5,2 \mathrm{H}), 7.92(\mathrm{~d}, J=9.1 \mathrm{~Hz}, \mathrm{H} 1, \mathrm{H} 8,2 \mathrm{H}), 7.71(\mathrm{~d}, J=9.1 \mathrm{~Hz}$, $\mathrm{H} 2, \mathrm{H} 7,2 \mathrm{H}), 3.64-3.45\left(\mathrm{~m}, 4 \times \mathrm{NCH}_{2}, 8 \mathrm{H}\right), 1.81-1.62\left(\mathrm{~m}, 4 \times \mathrm{NCH}_{2} \mathrm{CH}_{2}, 8 \mathrm{H}\right), 1.62-1.42$ $\left(\mathrm{m}, 4 \times \mathrm{NCH}_{2} \mathrm{CH}_{2} \mathrm{CH}_{2}, 8 \mathrm{H}\right) .{ }^{13} \mathrm{C} \mathrm{NMR}\left(150 \mathrm{MHz}, \mathrm{DMSO}-d_{6}\right) \delta 154.8(2 \times \mathrm{CO}), 149.8(\mathrm{C} 4 \mathrm{a}$, C10a), 142.4 (C3, C6), 134.6 (C9), 128.1 (C1, C8), 121.6 (C8a, C9a), 121.1 (C2, C7), 113.4 (C4, C5), $46.3\left(4 \times \mathrm{NCH}_{2}\right), 28.1\left(4 \times \mathrm{NCH}_{2} \mathrm{CH}_{2}\right), 26.6\left(4 \times \mathrm{NCH}_{2} \mathrm{CH}_{2} \mathrm{CH}_{2}\right)$. HRMS (ESI): $m / z$ calculated for $\mathrm{C}_{27} \mathrm{H}_{33} \mathrm{~N}_{5} \mathrm{O}_{2}[\mathrm{M}+\mathrm{H}]^{+} 460.27070$, found 460.27074 .

$N, N^{\prime}$-Acridine-3,6-diylbis( $N^{\prime}$-phenylurea) (11c, $\left.34 \mathrm{mg}, 73.1 \%\right)$. Yellow crystalline solid, $\mathrm{mp}>200{ }^{\circ} \mathrm{C}$ with decomposition. Thiourea was crystalized from the DMSO-diethyletermethanol mixture. ${ }^{1} \mathrm{H}$ NMR $\left(600 \mathrm{MHz}, \mathrm{DMSO}-d_{6}\right) \delta 9.36(\mathrm{~s}, 2 \times \mathrm{NH}, 2 \mathrm{H}), 9.00(\mathrm{~s}, 2 \times \mathrm{NH}$, 2H), 8.89 (s, H9, 1H), $8.31(\mathrm{~s}, \mathrm{H} 4, \mathrm{H} 5,2 \mathrm{H}), 8.05(\mathrm{~d}, J=9.1 \mathrm{~Hz}, \mathrm{H} 1, \mathrm{H} 8,2 \mathrm{H}), 7.60-7.50(\mathrm{~m}$, $\left.\mathrm{H} 2, \mathrm{H} 7,2 \times\left(\mathrm{H}^{\prime}, \mathrm{H6}^{\prime}\right), 6 \mathrm{H}\right), 7.40-7.30\left(\mathrm{~m}, 2 \times\left(\mathrm{H}^{\prime}, \mathrm{H}^{\prime}\right), 4 \mathrm{H}\right), 7.03-6.97\left(\mathrm{~m}, 2 \times \mathrm{H} 4^{\prime}, 2 \mathrm{H}\right)$. ${ }^{13} \mathrm{C}$ NMR $\left(150 \mathrm{MHz}, \mathrm{DMSO}-d_{6}\right) \delta 152.4(2 \times \mathrm{CO}), 148.9$ (C4a, C10a), 142.3 (C3, C6), 139.4 $\left(2 \times \mathrm{C}^{\prime}\right), 136.4(\mathrm{C} 9), 129.6(\mathrm{C} 1, \mathrm{C} 8), 128.9\left(2 \times\left(\mathrm{C}^{\prime}, \mathrm{C}^{\prime}\right)\right), 122.2\left(2 \times \mathrm{C}^{\prime}\right), 121.5(\mathrm{C} 8 \mathrm{a}$, C9a), $119.8(\mathrm{C} 2, \mathrm{C} 7), 118.4\left(2 \times\left(\mathrm{C}^{\prime}, \mathrm{C}^{\prime}\right)\right), 110.6(\mathrm{C} 4, \mathrm{C} 5)$. HRMS (ESI): $m / z$ calculated for $\mathrm{C}_{27} \mathrm{H}_{21} \mathrm{~N}_{5} \mathrm{O}_{2}[\mathrm{M}+\mathrm{H}]^{+}$448.17680, found 448.17961.

$N, N^{\prime}$-Acridine-3,6-diylbis( $N^{\prime}$-benzylthiourea) (11d, $\left.30 \mathrm{mg}, 64.0 \%\right)$. Yellow crystalline solid, $\mathrm{mp}>200{ }^{\circ} \mathrm{C}$ with decomposition. Thiourea was crystalized from the DMSOdiethyleter-methanol mixture. ${ }^{1} \mathrm{H}$ NMR $\left(600 \mathrm{MHz}, \mathrm{DMSO}-d_{6}\right) \delta 9.04(\mathrm{~s}, 2 \times \mathrm{NH}, 2 \mathrm{H})$, $8.72(\mathrm{~s}, \mathrm{H} 9,1 \mathrm{H}), 8.17(\mathrm{~s}, \mathrm{H} 4, \mathrm{H} 5,2 \mathrm{H}), 7.93(\mathrm{~d}, J=9.1 \mathrm{~Hz}, \mathrm{H} 1, \mathrm{H} 8,2 \mathrm{H}), 7.49(\mathrm{~d}, J=9.1 \mathrm{~Hz}$, $\mathrm{H} 2, \mathrm{H} 7,2 \mathrm{H}), 7.38-7.31\left(\mathrm{~m}, 2 \times\left(\mathrm{H}^{\prime}, \mathrm{H}^{\prime}\right), 4 \mathrm{H}\right), 7.38-7.31\left(\mathrm{~m}, 2 \times\left(\mathrm{H}^{\prime}, \mathrm{H}^{\prime}\right), 4 \mathrm{H}\right), 7.30-7.21$ $\left(\mathrm{m}, 2 \times \mathrm{H} 4^{\prime}, 2 \mathrm{H}\right), 6.84(\mathrm{t}, J=5.7 \mathrm{~Hz}, 2 \times \mathrm{NH}, 2 \mathrm{H}), 4.38\left(\mathrm{~d}, J=5.7 \mathrm{~Hz}, 2 \times \mathrm{NHCH}_{2}, 4 \mathrm{H}\right)$. ${ }^{13} \mathrm{C}$ NMR (150 MHz, DMSO- $\left.d_{6}\right) \delta 155.1(2 \times \mathrm{CO}), 150.1$ (C4a, C10a), 142.0 (C3, C6), 140.1 $\left(2 \times \mathrm{C}^{\prime}\right), 134.9(\mathrm{C} 9), 129.0(\mathrm{C} 1, \mathrm{C} 8), 128.4\left(2 \times\left(\mathrm{C}^{\prime}, \mathrm{C} 5^{\prime}\right)\right), 127.2\left(2 \times\left(\mathrm{C}^{\prime}, \mathrm{C}^{\prime}\right)\right), 126.8$ $\left(2 \times \mathrm{C}^{\prime}\right), 121.3$ (C8a, C9a), $119.5(\mathrm{C} 2, \mathrm{C} 7), 111.1(\mathrm{C} 4, \mathrm{C} 5), 42.9\left(2 \times \mathrm{NHCH}_{2}\right) . \mathrm{HRMS}(\mathrm{ESI})$ : $m / z$ calculated for $\mathrm{C}_{29} \mathrm{H}_{25} \mathrm{~N}_{5} \mathrm{O}_{2}[\mathrm{M}+\mathrm{H}]^{+} 476.20810$, found 476.20822 .

$N, N^{\prime}$-Acridine-3,6-diylbis( $\left.N^{\prime}-(4-m e t h y l p h e n y l) u r e a\right)(11 e, 30 \mathrm{mg}, 64.0 \%)$. Yellow crystalline solid, $\mathrm{mp}>200^{\circ} \mathrm{C}$ with decomposition. Thiourea was crystalized from the DMSOdiethyleter-methanol mixture. ${ }^{1} \mathrm{H}$ NMR $\left(400 \mathrm{MHz}, \mathrm{DMSO}-d_{6}\right) \delta 9.12(\mathrm{~s}, 2 \times \mathrm{NH}, 2 \mathrm{H})$, 8.81-8.76 (m, H9, NH, 2H), 8.24 (s, H4, H5, 2H), 8.00 (d, J = 9.1 Hz, H1, H8, 2H), 7.53 (d, $J=9.1 \mathrm{~Hz}, \mathrm{H} 2, \mathrm{H} 7,2 \mathrm{H}), 7.41\left(\mathrm{~d}, J=7.3 \mathrm{~Hz}, 2 \times\left(\mathrm{H2}^{\prime}, \mathrm{Hb}^{\prime}\right), 4 \mathrm{H}\right), 7.13\left(\mathrm{~d}, J=7.3 \mathrm{~Hz}, 2 \times\left(\mathrm{H}^{\prime}\right.\right.$, $\left.\left.\mathrm{H}^{\prime}\right), 4 \mathrm{H}\right), 2.26\left(\mathrm{~s}, 2 \times \mathrm{CH}_{3}, 6 \mathrm{H}\right) .{ }^{13} \mathrm{C}$ NMR $\left(100 \mathrm{MHz}, \mathrm{DMSO}-d_{6}\right) \delta 152.5(2 \times \mathrm{CO}), 150.0$ (C4a, C10a), 141.5 (C3, C6), $136.9\left(2 \times \mathrm{C}^{\prime}\right), 135.5$ (C9), $131.0\left(2 \times \mathrm{C}^{\prime}\right), 129.3\left(2 \times\left(\mathrm{C}^{\prime}\right.\right.$, C5')), 129.2 (C1, C8), 121.6 (C8a, C9a), 119.7 (C2, C7), 118.6 (2 × (C2', C6')), 111.8 (C4, C5), $20.4\left(2 \times \mathrm{CH}_{3}\right)$. HRMS (ESI): $m / z$ calculated for $\mathrm{C}_{29} \mathrm{H}_{25} \mathrm{~N}_{5} \mathrm{O}_{2}[\mathrm{M}+\mathrm{H}]^{+} 476.20810$, found 476.20803 .

$N, N^{\prime}$-Acridine-3,6-diylbis(N'-(2-phenylethyl)urea) (11f, $35 \mathrm{mg}$, 74.5\%). Yellow crystalline solid, $\mathrm{mp}>200{ }^{\circ} \mathrm{C}$ with decomposition. Thiourea was crystalized from the DMSOdiethyleter-methanol mixture. ${ }^{1} \mathrm{H}$ NMR $\left(600 \mathrm{MHz}, \mathrm{DMSO}-d_{6}\right) \delta 8.95(\mathrm{~s}, 2 \times \mathrm{NH}, 2 \mathrm{H})$, $8.70(\mathrm{~s}, \mathrm{H} 9,1 \mathrm{H}), 8.15(\mathrm{~s}, \mathrm{H} 4, \mathrm{H} 5,2 \mathrm{H}), 7.92(\mathrm{~d}, J=9.1 \mathrm{~Hz}, \mathrm{H} 1, \mathrm{H} 8,2 \mathrm{H}), 7.45(\mathrm{~d}, J=9.1 \mathrm{~Hz}$, $\mathrm{H} 2, \mathrm{H} 7,2 \mathrm{H}), 7.37-7.30\left(\mathrm{~m}, 2 \times\left(\mathrm{H}^{\prime}, \mathrm{H}^{\prime}\right), 4 \mathrm{H}\right), 7.28\left(\mathrm{~d}, J=7.3 \mathrm{~Hz}, 2 \times\left(\mathrm{H} 2^{\prime}, \mathrm{H} 6^{\prime}\right), 4 \mathrm{H}\right)$, 7.23-7.21 (m, $\left.2 \times \mathrm{H}^{\prime}, 2 \mathrm{H}\right), 6.33(\mathrm{t}, J=5.7 \mathrm{~Hz}, 2 \times \mathrm{NH}, 2 \mathrm{H}), 3.42\left(\mathrm{~m}, 2 \times \mathrm{NHCH}_{2}, 4 \mathrm{H}\right), 2.81$ $\left(\mathrm{t}, J=6.4 \mathrm{~Hz}, 2 \times \mathrm{NHCH}_{2} \mathrm{CH}_{2}, 4 \mathrm{H}\right) .{ }^{13} \mathrm{C} \mathrm{NMR}\left(150 \mathrm{MHz}, \mathrm{DMSO}-d_{6}\right) \delta 155.0(2 \times \mathrm{CO}), 150.1$ (C4a, C10a), $142.0(\mathrm{C} 3, \mathrm{C} 6), 139.5\left(2 \times \mathrm{C}^{\prime}\right), 134.9$ (C9), $129.0(\mathrm{C} 1, \mathrm{C} 8), 128.7\left(2 \times\left(\mathrm{C}^{\prime}, \mathrm{C} 6{ }^{\prime}\right)\right)$, $128.4\left(2 \times\left(\mathrm{C}^{\prime}, \mathrm{C}^{\prime}\right)\right), 126.1\left(2 \times \mathrm{C}^{\prime}\right), 121.3$ (C8a, C9a), 119.4 (C2, C7), $111.0(\mathrm{C} 4, \mathrm{C} 5), 40.7$ $\left(2 \times \mathrm{NHCH}_{2} \mathrm{CH}_{2}\right), 35.7\left(2 \times \mathrm{NHCH}_{2} \mathrm{CH}_{2}\right)$. HRMS (ESI): $m / z$ calculated for $\mathrm{C}_{31} \mathrm{H}_{29} \mathrm{~N}_{5} \mathrm{O}_{2}$ $[\mathrm{M}+\mathrm{H}]^{+}$504.23940, found 504.24187.

$N, N^{\prime}$-Acridine-3,6-diylbis( $N^{\prime}-(2-m e t h y l b e n z y l)$ thiourea) $(\mathbf{1 1 g}, 35 \mathrm{mg}, 74.5 \%)$. Yellow crystalline solid, $\mathrm{mp}>20{ }^{\circ} \mathrm{C}$ with decomposition. Thiourea was crystalized from the DMSOdiethyleter-methanol mixture. ${ }^{1} \mathrm{H}$ NMR $\left(400 \mathrm{MHz}, \mathrm{DMSO}-d_{6}\right) \delta 9.00(\mathrm{~s}, 2 \times \mathrm{NH}, 2 \mathrm{H}), 8.71$ 
(s, H9, 1H), 8.16 (s, H4, H5, 2H), 7.93 (d, J = 9.1 Hz, H1, H8, 2H), 7.48 (d, J = 9.1 Hz, H2, H7, $2 \mathrm{H}), 7.24\left(\mathrm{~d}, J=7.3 \mathrm{~Hz}, 2 \times\left(\mathrm{H} 2^{\prime}, \mathrm{H} 6^{\prime}\right), 4 \mathrm{H}\right), 7.16\left(\mathrm{t}, J=7.5 \mathrm{~Hz}, 2 \times\left(\mathrm{H}^{\prime}{ }^{\prime}, \mathrm{H} 5^{\prime}\right), 4 \mathrm{H}\right), 6.77(\mathrm{t}$, $J=5.7 \mathrm{~Hz}, 2 \times \mathrm{NH}, 2 \mathrm{H}), 4.32\left(\mathrm{~d}, J=5.7 \mathrm{~Hz}, \mathrm{NHCH}_{2}, 4 \mathrm{H}\right), 2.28\left(\mathrm{~s}, 2 \times \mathrm{CH}_{3}, 6 \mathrm{H}\right) .{ }^{13} \mathrm{C} \mathrm{NMR}$ $\left(100 \mathrm{MHz}, \mathrm{DMSO}-d_{6}\right) \delta 155.0(2 \times \mathrm{CO}), 150.1(\overline{\mathrm{C} 4 \mathrm{a}}, \mathrm{C} 10 \mathrm{a}), 142.0(\mathrm{C} 3, \mathrm{C} 6), 137.0\left(2 \times \mathrm{C}^{\prime}\right)$, $135.9\left(2 \times \mathrm{C}^{\prime}\right), 135.0(\mathrm{C} 9), 129.0(\mathrm{C} 1, \mathrm{C} 8), 128.9\left(2 \times\left(\mathrm{C}^{\prime}, \mathrm{C}^{\prime}\right)\right), 127.2\left(2 \times\left(\mathrm{C}^{\prime}, \mathrm{C}^{\prime}\right)\right), 121.3$ (C8a, C9a), $119.5(\mathrm{C} 2, \mathrm{C} 7), 111.1(\mathrm{C} 4, \mathrm{C} 5), 42.6\left(2 \times \mathrm{NHCH}_{2}\right), 20.7\left(2 \times \mathrm{CH}_{3}\right) . \mathrm{HRMS}(\mathrm{ESI})$ : $m / z$ calculated for $\mathrm{C}_{31} \mathrm{H}_{29} \mathrm{~N}_{5} \mathrm{O}_{2}[\mathrm{M}+\mathrm{H}]^{+}$504.23940, found 504.24140.

$N, N^{\prime}$-Acridine-3,6-diylbis(N'-[(1S)-1-phenylethyl]urea) (11h, 30 mg, 63.8\%). Yellow crystalline solid, $\mathrm{mp}>200{ }^{\circ} \mathrm{C}$ with decomposition. Thiourea was crystalized from the diethyletern-hexane mixture. ${ }^{1} \mathrm{H}$ NMR $\left(600 \mathrm{MHz}, \mathrm{DMSO}-d_{6}\right) \delta 8.85(\mathrm{~s}, 2 \times \mathrm{NH}, 2 \mathrm{H}), 8.70(\mathrm{~s}, \mathrm{H} 9,1 \mathrm{H})$, 8.10 (s, H4, H5, 2H), 7.92 (d, J = 9.1 Hz, H1, H8, 2H), 7.44 (d, J = 9.1 Hz, H2, H7, 2H), 7.38 $\left(\mathrm{d}, J=7.3 \mathrm{~Hz}, 2 \times\left(\mathrm{H} 2^{\prime}, \mathrm{H6}^{\prime}\right), 4 \mathrm{H}\right), 7.36-7.32\left(\mathrm{~m}, 2 \times\left(\mathrm{H}^{\prime}, \mathrm{H} 5^{\prime}\right), 4 \mathrm{H}\right), 7.28-7.21\left(\mathrm{~m}, 2 \times \mathrm{H} 4^{\prime}\right.$, $2 \mathrm{H}), 6.83(\mathrm{~d}, J=5.7 \mathrm{~Hz}, 2 \times \mathrm{NH}, 2 \mathrm{H}), 4.95-4.84(\mathrm{~m}, 2 \times \mathrm{NHCH}, 2 \mathrm{H}), 1.43(\mathrm{~d}, J=7.0 \mathrm{~Hz}$, $\left.2 \times \mathrm{CH}_{3}, 6 \mathrm{H}\right) .{ }^{13} \mathrm{C}$ NMR $\left(150 \mathrm{MHz}, \mathrm{DMSO}-d_{6}\right) \delta 154.2(2 \times \mathrm{CO}), 150.0(\mathrm{C} 4 \mathrm{a}, \mathrm{C} 10 \mathrm{a}), 145.0$ $\left(2 \times \mathrm{C}^{\prime}\right), 141.9(\mathrm{C} 3, \mathrm{C} 6), 135.0(\mathrm{C} 9), 129.1(\mathrm{C} 1, \mathrm{C} 8), 128.4\left(2 \times\left(\mathrm{C}^{\prime}, \mathrm{C}^{\prime}\right)\right), 126.8\left(2 \times \mathrm{C}^{\prime}\right)$, $125.9\left(2 \times\left(\mathrm{C}^{\prime}, \mathrm{C}^{\prime}\right)\right), 121.3$ (C8a, C9a), 119.4 (C2, C7), 110.9 (C4, C5), 48.7 (2 × NHCH), 23.0 $\left(2 \times \mathrm{CH}_{3}\right) \cdot[\alpha] D_{20}=+326.6$ (c 0.06 , DMSO). HRMS (ESI): $m / z$ calculated for $\mathrm{C}_{31} \mathrm{H}_{29} \mathrm{~N}_{5} \mathrm{O}_{2}$ $[\mathrm{M}+\mathrm{H}]^{+}$504.23940, found 504.24143.

$N, N^{\prime}$-Acridine-3,6-diylbis(N'-[(1R)-1-phenylethyl]urea) (11i, $\left.35 \mathrm{mg}, 74.5 \%\right)$. Yellow crystalline solid, $\mathrm{mp}>200{ }^{\circ} \mathrm{C}$ with decomposition. Thiourea was crystalized from the diethyletern-hexane mixture. ${ }^{1} \mathrm{H}$ NMR $\left(400 \mathrm{MHz}, \mathrm{DMSO}-d_{6}\right) \delta 8.85(\mathrm{~s}, 2 \times \mathrm{NH}, 2 \mathrm{H}), 8.70(\mathrm{~s}, \mathrm{H9}, 1 \mathrm{H})$, 8.11 (s, H4, H5, 2H), 7.93 (d, J = 9.1 Hz, H1, H8, 2H), 7.44 (d, J = 9.1 Hz, H2, H7, 2H), 7.38 $\left(\mathrm{d}, J=7.3 \mathrm{~Hz}, 2 \times\left(\mathrm{H}^{\prime}, \mathrm{H6}^{\prime}\right), 4 \mathrm{H}\right), 7.36-7.32\left(\mathrm{~m}, 2 \times\left(\mathrm{H}^{\prime}, \mathrm{H} 5^{\prime}\right), 4 \mathrm{H}\right), 7.28-7.21\left(\mathrm{~m}, 2 \times \mathrm{H}^{\prime}\right.$, $2 \mathrm{H}), 6.83(\mathrm{~d}, J=5.7 \mathrm{~Hz}, 2 \times \mathrm{NH}, 2 \mathrm{H}), 4.95-4.84(\mathrm{~m}, 2 \times \mathrm{NHCH}, 2 \mathrm{H}), 1.43(\mathrm{~d}, J=7.0 \mathrm{~Hz}$, $\left.2 \times \mathrm{CH}_{3}, 6 \mathrm{H}\right) .{ }^{13} \mathrm{C} \mathrm{NMR}\left(100 \mathrm{MHz}, \mathrm{DMSO}-d_{6}\right) \delta 154.2(2 \times \overline{\mathrm{CO}}), 150.0(\mathrm{C} 4 \mathrm{a}, \mathrm{C} 10 \mathrm{a}), 145.0$ $\left(2 \times \mathrm{C}^{\prime}\right), 141.9(\mathrm{C} 3, \mathrm{C} 6), 135.0(\mathrm{C} 9), 129.1(\mathrm{C} 1, \mathrm{C} 8), 128.4\left(2 \times\left(\mathrm{C}^{\prime}, \mathrm{C}^{\prime}\right)\right), 126.8\left(2 \times \mathrm{C}^{\prime}\right)$, $125.9\left(2 \times\left(\mathrm{C}^{\prime}, \mathrm{C}^{\prime}\right)\right), 121.3$ (C8a, C9a), 119.4 (C2, C7), 110.9 (C4, C5), 48.7 (2 × NHCH), 23.0 $\left(2 \times \mathrm{CH}_{3}\right) \cdot[\alpha] D_{20}=-326.6$ (c 0.06, DMSO). HRMS (ESI): $m / z$ calculated for $\mathrm{C}_{31} \mathrm{H}_{29} \mathrm{~N}_{5} \mathrm{O}_{2}$ $[\mathrm{M}+\mathrm{H}]^{+}$504.23940, found 504.24133.

$N, N^{\prime}$-Acridine-3,6-diylbis( $N^{\prime}$-hexylurea) (11j, $\left.35 \mathrm{mg}, 31.2 \%\right)$. All physicochemical properties were in accordance with previously published data [14].

\subsection{Biology \\ 3.3.1. Cell Line}

BJ-5ta (ATCC CRL-4001) (immortalized foreskin fibroblasts) were obtained from ATCC and cultured in Dulbecco's Modified Eagle's Medium (DMEM) supplemented with M199 medium (4:1), Hygromycin B $(0.01 \mathrm{mg} / \mathrm{mL})$ and $10 \%$ of FBS (fetal bovine serum) in the presence of $5 \% \mathrm{CO}_{2}$ in a humidified atmosphere at $37^{\circ} \mathrm{C}$.

\subsubsection{Agilent $x$ CELLigence Real-Time Cell Analysis}

Fibroblast cells $\left(5 \times 10^{3}\right.$ cells/well) were seeded in 96-well plates (RTCA E-Plates 96) on $x$ CELLigence RTCA systems (Agilent). The cells were treated with derivatives 11b, 11c, 11f, 11j and amsacrine $24 \mathrm{~h}$ after seeding. Fibroblast cells were cultured in the absence or presence of tested drugs at concentrations ranging from $100 \mu \mathrm{M}$ to $100 \mathrm{nM}$. The cell adhesion and spread without the manipulation of the cells were continuously monitored in 60 min intervals over the course of a $120 \mathrm{~h}$ observation period using the $x$ CELLigence RTCA system.

\section{Statistical Analysis}

Experiments under all conditions were performed in at least three independent measurements. The data were analyzed by using the RTCA software Pro 1.2.1 (ACEA Bioscience). Statistical analysis was carried out by a non-parametric method, one-way ANOVA using SigmaPlot (Ver. 12.0). A $p<0.05$ was considered significant. 


\subsubsection{Screening of Anticancer Activity-NCI-60 Panels}

The anticancer activity of proflavine ureas 11a-11j was tested against NCI-60 panels consisting of sixty human cancer cell lines. Derivatives $\mathbf{1 1 a} \mathbf{- 1 1} \mathbf{j}$ were initially at a single dose of $10 \mu \mathrm{M}$ to identify the individual derivatives with the highest level of growth inhibition. Urea derivatives 11b, 11c, 11f and 11j were found to have exhibited significant growth inhibition in the One-Dose Screen, and these derivatives were further evaluated against NCI-60 panels at five concentration levels to determine the growth inhibition concentration, $\mathrm{GI}_{50}$. The $\mathrm{GI}_{50}$ values for doxorubicin, fluorouracil and cisplatin were downloaded from the NCI data repository (https:/ /dtp.cancer.gov/databases_tools/data_search.htm).

The screening protocol is described on the web page: https:/ / dtp.cancer.gov / discovery_ development/nci-60/methodology.htm.

\subsection{Molecular Modeling}

\subsubsection{Normal Mode Analysis}

To build urea models I-XXIII, 3D Viewer (ver. 11.01) and ChemSketch (ver. 11.02) software as components of the ACD Labs software package were used [16]. Molecular design studies were performed with Gabedit [19] and MOPAC2016 software using the PM7 method [17]. The optimization of models I-XXIII was controlled by the commands: LET; DDMIN $=0 ;$ GNORM $=0.1 ; \mathrm{AUX} ; \mathrm{EPS}=78 ; \mathrm{EF} ; \mathrm{XYZ}$. The post-processing normal modes analysis was controlled using the keywords: FORCE; THERMO; PRECISE; EPS $=78$.

\subsubsection{Calculation of $\Delta S^{\circ}$ Value}

The change in the standard entropy, $\Delta S^{\circ}$, of specific urea models was calculated using the value of the standard entropy, $S^{\circ}$, at a temperature of 300 and 340 degrees of Kelvin. The values of the standard entropy are listed in the Mopac output file.

$$
\Delta S^{\circ}=S^{\circ}{ }_{340 \mathrm{~K}}-S^{\circ}{ }_{300 \mathrm{~K}}
$$

\subsubsection{Calculation of $\log P$ Value}

$\log P$ calculations were performed using the "Calculation of Molecular Properties and Prediction of Bioactivity" module within the options of the Molinspiration web tool in order to obtain the $\log P$ value of individual urea models [18].

\subsubsection{Calculation of Score Value}

The score value of individual urea models was obtained as the sum of the $\log P$ value and the $\Delta S^{\circ}$ value.

$$
\text { Score value }=\log P+\Delta S^{\circ}
$$

\section{Conclusions}

Building on our previous studies on the urea derivatives $\mathbf{1 1} \mathbf{j}-\mathbf{1 1 n}$, the pharmacological model was developed in order to facilitate the design of novel urea-based proflavine intercalators which could act as cytostatic substances. The model using a scoring system that utilized the lipophilicity and the change in the standard entropy for individual structures. The physicochemical values of $\log P$ and $\Delta S^{\circ}$ were obtained through a theoretical approach. In order for a given urea model to be synthesized for in vitro screening, it was necessary to achieve a score value which fell within the score range defined by the structure-activity relationship for ureas 11j-11n. Using this scoring system, urea models VIII-XIV, XVII and XVIII were selected as the leading models for synthesis from which all had at least six carbon atoms in their chains.

An improved protocol was applied in the preparation of the urea derivatives in which the yield of the synthesis of 3,6-diisotiocyanatoacridine (9) was enhanced substantially, from the previous yield of $53 \%$ to $83 \%$.

Urea derivatives $\mathbf{1 1 a}-\mathbf{1 1} \mathbf{j}$ were subjected to further investigation through in vitro screening against NCI-60 human cancer cell lines in order to determine their anticancer activity. The strongest cytostatic effect was exhibited by azepyl 11b, phenyl 11c and 
phenylethyl urea 11f, all of which inhibited the growth of cancer cell lines even at submicromolar concentrations, while ureas 11a, 11d, 11e, 11g, 11h and 11i displayed no effect whatsoever. In comparison to hexyl urea $\mathbf{1 1} \mathbf{j}$, the parent structure in the preceding molecular design study, the cytostatic activity of ureas 11b, 11c and 11f was found to have improved only slightly, but this moderate improvement is in line with the results of the scoring system based on opposing physicochemical properties. In contrast, the cytotoxicity of ureas 11b, 11c and 11f was more than three orders of magnitude lower than the cytotoxicity of urea 11j. In summary, this is the main outcome of the study, especially compared to hexylurea $\mathbf{1 1} \mathbf{j}$, which showed almost no selectivity for tumor cells over non-cancer cells.

In conclusion, a series of novel proflavine ureas, derivatives 11a-11i, were synthesized based on molecular modeling design studies. The structure of the novel ureas was proposed on the basis of the pharmacological model. The lipophilicity $(\log P)$ and the changes in the standard entropy $\left(\Delta S^{\circ}\right)$, as the input parameters of the pharmacological model, were obtained using quantum mechanics and cheminformatics. The pharmacological model is based on a scoring system, in which urea models are required to achieve within a specific range in order to be considered suitable for synthesis. The anticancer activity of the synthesized derivatives was evaluated against NCI-60 human cancer cell lines. The strongest anticancer activity was exhibited by ureas azepyl 11b, phenyl 11c and phenylethyl 11f, although the levels of activity were only a slight improvement on those recorded for hexyl urea 11j. The $\mathrm{GI}_{50}$ values recorded for the derivatives against HCT-116 cancer cell line give an indication of the cytostatic effect of the ligands azepyl 11b- $-0.44 \mu \mathrm{M}$, phenyl 11c $-0.23 \mu \mathrm{M}$, phenylethyl 11f $-0.35 \mu \mathrm{M}$ and hexyl $11 \mathrm{j}-0.36 \mu \mathrm{M}$. In contrast, the novel ureas $\mathbf{1 1 b}, \mathbf{1 1 c}$ and 11f exhibited levels of cytotoxicity three orders of magnitude lower than that of hexyl urea 11j.

Supplementary Materials: The following are available online. Tables S1-S4; Figures S1 and S2 and ${ }^{1} \mathrm{H},{ }^{13} \mathrm{C}$ NMR spectra of the synthetized compounds.

Author Contributions: Conceptualization, L.J., M.K. (Maria Kozurkova); methodology, L.J.; validation, L.J., M.K. (Maria Kozurkova) and M.S.; formal analysis, L.J.; investigation, L.J., E.K., M.S., M.K. (Monika Kvakova), D.K., D.J.; resources, M.K. (Maria Kozurkova); data curation, L.J., M.K. (Maria Kozurkova); writing—original draft preparation, L.J.; writing—review and editing, L.J., M.K. (Maria Kozurkova); visualization, L.J., M.S.; supervision, M.K. (Maria Kozurkova), L.J.; project administration, M.K. (Maria Kozurkova); funding acquisition, M.K. (Maria Kozurkova) All authors have read and agreed to the published version of the manuscript.

Funding: This research was funded by the Ministry of Education, Science, Research and Sport of the Slovak Republic and the Slovak Academy of Sciences (SAS) (Slovak Grant Agency VEGA, grant No. 1/0016/18) and by the Czech Ministry of Health (UHHK grant No. 00179906).

Institutional Review Board Statement: Not applicable.

Informed Consent Statement: Not applicable.

Data Availability Statement: The data presented in this study are available in the article and Supplementary Materials. The $\mathrm{GI}_{50}$ values for doxorubicin, fluorouracil, cisplatin, ureas 11b, 11c, 11f and $11 \mathbf{j}$ were downloaded from the NCI data repository (https://dtp.cancer.gov/databases_ tools/data_search.htm; https://dtp.cancer.gov/dtpstandard/dwindex/index.jsp). NCS compound identifier: 119875-cisplatin; 19893-fluouracil; 249992-amsacrine; 759155-doxorubicine; 80428111b (azepyl); 804282-11b (phenyl); 804286-11f (phenylethyl); 804279-11j ( $n$-hexyl).

Acknowledgments: The authors are also grateful to the National Institute of Health (NIH), National Cancer Institute Branch for the opportunity to use their Developmental Therapeutic Program (DTP) for the timely screening of our compounds using NCI-60 panels.

Conflicts of Interest: The authors declare no conflict of interest.

Sample Availability: Not applicable. 


\section{References}

1. Gensicka-Kowalewska, M.; Cholewiński, G.; Dzierzbicka, K. Recent developments in the synthesis and biological activity of acridine/acridone analogues. RSC Adv. 2017, 7, 15776-15804. [CrossRef]

2. Demeunynck, M. Antitumour acridines. Expert Opin. Ther. Patents 2004, 14, 55-70. [CrossRef]

3. Lerman, L.S. The structure of the DNA-acridine complex. Proc. Natl. Acad. Sci. USA 1963, 49, 94-102. [CrossRef] [PubMed]

4. Adams, A. Crystal structures of acridines complexed with nucleic acids. Curr. Med. Chem. 2002, 9, 1667-1675. [CrossRef] [PubMed]

5. Belmont, P.; Dorange, I. Acridine/acridone: A simple scaffold with a wide range of application in oncology. Expert Opin. Ther. Patents 2008, 18, 1211-1224. [CrossRef]

6. Blackburn, G.M.; Gait, M.J.; Loakes, D.; Williams, D.M. Nucleic Acids in Chemistry and Biology, 3rd ed.; The Royal Society of Chemistry: London, UK, 2006.

7. Belmont, P.; Bosson, J.; Godet, T.; Tiano, M. Acridine and acridone derivatives, anticancer properties and synthetic methods: Where are we now? Anti-Cancer Agent. Med. Chem. 2007, 7, 139-169. [CrossRef] [PubMed]

8. Harrison, R.J.; Gowan, S.M.; Kelland, L.R.; Neidle, S. Human telomerase inhibition by substituted acridine derivatives. Bioorg. Med. Chem. Lett. 1999, 9, 2463-2468. [CrossRef]

9. Harrison, R.J.; Cuesta, J.; Chessari, G.; Read, M.A.; Basra, S.K.; Reszka, A.P.; Morrell, J.; Gowan, S.M.; Incles, C.M.; Tanious, F.A.; et al. Trisubstituted acridine derivatives as potent and selective telomerase inhibitors. J. Med. Chem. 2003, 46, $4463-4476$. [CrossRef] [PubMed]

10. Hamissa, M.F.; Niederhafner, P.; Šafařík, M.; Telus, M.; Kolářová, L.; Koutná, L.; Šestáková, H.; Souček, R.; Šebestík, J. Total synthesis of inubosin B. Tetrahedron Lett. 2020, 61, 152641. [CrossRef]

11. Gatasheh, M.K.; Kannan, S.; Hemalatha, K.; Imrana, N. Proflavine an acridine DNA intercalating agent and strong antimicrobial possessing potential properties of carcinogen. Karbala Int. J. Mod. Sci. 2017, 3, 272-278. [CrossRef]

12. Wainwright, M. Acridine-A neglected antibacterial chromophore. J. Antimicrob. Chemoth. 2001, 47, 1-13. [CrossRef] [PubMed]

13. Valdés, A.F.-C. Acridine and acridinones: Old and new structures with antimalarial activity. Open Med. Chem. J. 2011, 5, 11-20. [CrossRef] [PubMed]

14. Kožurková, M.; Sabolová, D.; Janovec, L.; Mikeš, J.; Koval', J.; Ungvarský, J.; Štefanišinová, M.; Fedoročko, P.; Kristian, P.; Imrich, J. Cytotoxic activity of proflavine diureas: Synthesis, antitumor, evaluation and DNA binding properties of $1^{\prime}, 1^{\prime \prime}$-(acridin-3,6diyl)-3',3"'-dialkyldiureas. Bioorg. Med. Chem. 2008, 16, 3976-3984. [CrossRef] [PubMed]

15. Genheden, S.; Ryde, U. The MM/PBSA and MM/GBSA methods to estimate ligand-binding affinities. Expert Opin. Drug Discov. 2015, 10, 449-461. [CrossRef]

16. ACD. ChemSketch Package 2020.2.0. Available online: www.acdlabs.com (accessed on 27 July 2021).

17. Stewart, J.J.P. Stewart Computational Chemistry. Available online: http:/ / openmopac.net (accessed on 27 July 2021).

18. Molinspiration Cheminformatics Free Web Services. Slovensky Grob, Slovakia. Available online: https://www.molinspiration. com (accessed on 27 July 2021).

19. Allouche, A.-R. Gabedit-A graphical user interface for computational chemistry softwares. J. Comput. Chem. 2011, 32, 174-182. [CrossRef] [PubMed] 